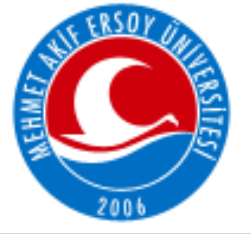

\author{
MEHMET AKIF ERSOY ÜNIVERSITESI \\ SAĞLIK BİLIMLERİ ENSTITÜSÜ DERGİSI \\ "MAKÜ Sag. Bil. Enst. Derg." \\ http://edergi.mehmetakif.edu.tr/index.php/sabed/index
}

\title{
Köpeklerde Midazolam-Ketamin-İzofloran ve Midazolam- Propofol-İzofloran Anestezisinin Koagulasyon Parametrelerine Etkisinin Araştırılması
}

\author{
Evaluation of the Effects of Midazolam-Ketamine-Isoflurane and Midazolam- \\ Propofol- Isoflurane Anesthesia on Coagulation Parameters in Dogs. \\ Pınar Arca ${ }^{1}$, Zülfükar Kadir Sarıtaş ${ }^{*}$
}

${ }^{1}$ Afyon Kocatepe Üniversitesi Veteriner Fakültesi, Cerrahi Anabilim Dalı, Afyonkarahisar/TÜRKIYY.

\begin{abstract}
The aim of this study was to evaluate the effects of Midazolam- Ketamine-Isoflorane (MKI) ve MidazolamPropofol-Isoflorane (MPI) anesthesia on coagulation parameters, vital parameters, hemogram parameters, blood gas parameters and biochemical parameters.

The study was held on varying breed, race and gendered total 20 dogs aging between 4 months to 6 years that were brought for various reasons taken under surgical intervention to Afyon Kocatepe University animal Hospital. Dogs were randomly grouped as MKI $(n=10)$ and MPI $(n=10)$. MKI and MPI groups dogs were premedicated with midazolam 0,2-0,4 $\mathrm{mg} / \mathrm{kg}$ intravenously following fasting period for 12 hours. MKI group anesthesia were induced by the injection of ketamine $15 \mathrm{mg} / \mathrm{kg}$ and in MPI group by the slow injection of propofol $6-7 \mathrm{mg} / \mathrm{kg}$ by i.v. Both group dogs were intubated with endotracheal tube and general anaesthesi was achieved by Isoflurane $2 \%$.

Blood samples were collected from all group dogs at $0^{\text {th }}, 15^{\text {th }}$ And $30^{\text {th }}$ minutes and postoperatively $0^{\text {th }} \mathrm{min}$. and $6^{\text {th }}$ hour for the measurement of hemogram blood gases and coagulation parameters together with the collection of vital parameters. When the groups were compared, preoperative $0^{\text {th }}$ minute measurements PT, TT fibrinogen and APTT values were insinificantly changed statistically $(\mathrm{p}>0.05)$. All the time period measurements were found between normal values.

Within the results of measurements, both anesthesia protocol was found safe and convenient in the use of dogs' anesthesia for the mean of coagulation parameters, vital parameters, blood gas parameters hemogram parameters and biochemical parameters.
\end{abstract}

Key words: Dogs, Midazolam, Ketamin $\mathrm{HCl}$, Propofol, Isoflurane.

Yazışma Adresi: Prof.Dr. Zülfükar Kadir SARITAȘ. Afyon Kocatepe Üniversitesi Veteriner Fakültesi, Cerrahi Anabilim Dalı.A.N.S Kampüsü. Gazlıgöl Yolu. 03200. AFYONKARAHISAR.

E-posta: zksaritas@hotmail.com

Tel: +905054487202

Kaynak göstermek için: Arca P, Sarıtaş Z.K. 2017 Köpeklerde Midazolam-Ketamin-İzofloran ve Midazolam-Propofol-İzofloran Anestezisinin Koagulasyon Parametrelerine Etkisinin Araştırılması. MAKÜ Sag. Bil. Enst. Derg. 5(2): 93-114.
Öz: Bu çalışmanın amacı, köpeklerde Midazolam- Ketaminİzofloran (MKİ) ve Midazolam-Propofol-İzofloran (MPI) anestezisinin koagülasyon parametreleri, vital parametreler, hemogram parametreleri, kan gazı parametreleri, biyokimyasal parametreler üzerindeki etkisinin araştırılmasıdır. Çalışmada, Afyon Kocatepe Üniversitesi Veteriner Sağlık Uygulama ve Araştırma Merkezine çeşitli operasyonlar yapılması amacıyla getirilen, farklı ırktan, farklı cinsiyetten ve yaşları 4 ay ile 6 yaş arası değişen 20 adet köpek kullanıldı. Köpekler rastgele (MKİ $n=10)$ ve (MPİ $n=10)$ iki gruba ayrildı. MKI protokolü uygulanan köpeklerde 12 saat açlığı takiben Preanestezik olarak midazolam 0,2-0,4 mg/kg dozda intravenöz yolla uygulandi. Anestezi indüksiyonu Ketamin $\mathrm{HCl}$ 'ün $15 \mathrm{mg} / \mathrm{kg}$ dozda intravenöz uygulanmasıyla sağlandı. MPİ protokolü uygulanan köpeklerde 12 saat açlığı takiben preanestezik olarak midazolam 0,2-0,4 $\mathrm{mg} / \mathrm{kg}$ dozda intravenöz kullanıldı. Anestezi indüksiyonu; propofol solüsyonunun 6-7 $\mathrm{mg} / \mathrm{kg}$ dozda intravenöz yolla yavaş şekilde enjekte edilmesiyle sağlandı. Hemen ardından iki gruptaki köpeklere uygun çaptaki endotrakeal tüplerle entübasyon gerçekleştirildi ve genel anestezi \%2 izofluran ile sağlandı. Gruplar karşılaştırıldığında preoperatif 0 . dakika ölçümlerine göre tüm ölçüm zamanlarında PT, TT, Fibrinojen ve APTT değerlerinde istatistiksel önemi olmayan $\quad(p>0.05)$ değişim kaydedildi ve tüm ölçüm zamanlarındaki bulgular referans aralıktaydı. Yapılan ölçümler sonucunda, her iki anestezi protokolününde; koagülasyon parametreleri, vital parametreler, kan gazı parametreleri, hemogram parametreleri ve biyokimyasal parametreler göz önüne alınarak köpeklerde güvenle kullanılabileceği sonucuna varildi.

Anahtar sözcükler: Köpek, Midazolam, Ketamin $\mathrm{HCl}$, Propofol, İzofloran

Geliş Tarihi: 12.11.2017 Kabul Tarihi: 21.11.2017 


\section{Giriş}

İdeal bir anestezi protokolünde anestezik ajanlar sakin, komplikasyonsuz bir anestezi sağlamakla birlikte hayati organları çok az veya hiç etkilememektedirler. Tek bir analjezik ajan bunu sağlayamadığından farklı ilaç kombinasyonları kullanılmaktadır (Koç ve Sarıtaş, 2004).

Batı yarım küresinin keşfinden önce Güney Amerika yerlileri tarafından kullanıldığı bilinen, hayvanlarda ilk kez 1811'de Brodie tarafından kullanılan kas gevşeticilerin veteriner anesteziyoloji alanındaki klinik kullanımı, ilk olarak 1952 yılında Hall tarafindan bildirilmiştir. $\mathrm{Bu}$ gelişmeyle birlikte; anestezi, analjezi ve kas gevşemesinin bir arada gerçekleştirilmesini kapsayan 'dengeli anestezi' kavramı da veteriner hekimliği uygulamaları arasında yerini almıştır (Şenel ve Koç, 2008).

Hasara uğramış kan damarlarından kan kaybının önlenmesi işine hemostazis denir. Hemostazisin başlıca üç komponenti vardır. Bunlar; vasküler bütünlük, trombosit sayısı ve fonksiyonu ve kan koagülasyonudur (Turgut ve ark., 2000).

Kanama hastalıklarının tanısında klinik olarak bukkal mukozal kanama süresinin belirlenmesiyle birlikte, laboratuvar düzeyinde sitratlı plazma örneklerinden trombosit sayıları ve koagülasyon profilinin değerlendirilmesi önerilmektedir. Koagülasyon profilinde PT, APTT, fibrinojen ve AT-III düzeylerinin tespiti gerekmektedir. Bukkal mukoza kanama süresi tayini klinik düzeyde uygulanmakla birlikte kanama hastalıkları tanısında önemli bir indikatör olarak kabul edilmemektedir. Kanama bozukluklarının gelişiminde damar çeperi, koagülasyon proteinleri ve trombositlerden oluşan bir sistemin bir ya da bir kaçındaki patolojik değişimler rol oynamaktadır. Trombosit sayısı kanama hastalıklarının belirlenmesinde klinik düzeyde kullanılabilecek önemli tanısal bir kriter olarak kabul edilmektedir (Kennerman ve Kaya, 2005).

Genel anestezinin kan parametrelerine etkisinin araştırılması, güvenli anesteziklerin bulunması yönünden ve anestezi protokolünün hastaya uygunluğunun değerlendirilmesi açısından önemlidir (Çetinaslan ve Apaydın, 2008).

$\mathrm{Bu}$ araştırmada, köpeklerde farklı operatif girişimlerde uygulanan MidazolamKetamin-İzofloran (MKİ) ve Midazolam-Propofol-İzofloran (MPİ) anestezisinin koagülasyon 
parametreleriyle birlikte biyokimyasal, hematolojik parametreler ve kan gazları üzerine olan etkilerinin araştırılması amaçlanmıştır.

\section{Gereç ve Yöntem}

Anestezik girişimler, otomatik ventilatörlü ve dijital kumandalı, çift vaporizatörlü kapalı sistemle çalışan ve soda-lime'lı SMS (SMS 2000 Vent-V Model) marka anestezi cihazı aracılığıyla gerçekleştirildi. Tam kan ölçümleri için Mindray BC-2800 VET (Auto Hematology Analyser ALMANYA) cihazı kullanıldı. Koagülasyon parametreleri ölçümleri MT-TC (TOKRA, TÜRKIYE) cihazı kullanılarak ölçüldü. Kan gazı ölçümleri için EPOC Blood Analyses, (Woodley Equipment Company ABD) kan gazı analiz cihazı kullanılarak ölçüldü ve ölçülen parametreler kaydedildi.

\section{Hayvan materyali}

Bu çalışmada Afyon Kocatepe Üniversitesi, Veteriner Sağlık Uygulama ve Araştırma Merkezi'ne çeşitli operasyonlar yapılması amacıyla getirilen, farklı 1rktan, farklı cinsiyetten ve yaşları 4 ay ile 6 yaş arası değişen 20 köpeğin (Tablo 1), kan gazı, hemogram, koagülasyon ve vital parametreleri değerlendirildi. 20 köpek rastgele iki gruba ayrıldı. Birinci grup Midazolam-Ketamin-İzofloran (MKİ) (n=10) ve ikinci grup Midazolam-Propofol-İzofloran (MPİ) ( $\mathrm{n}=10)$ olarak değerlendirildi. Çalışmada MKİ protokolü uygulanan köpeklerin ağırlık

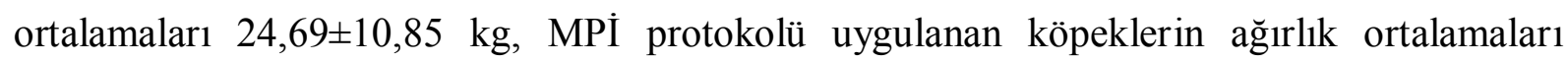

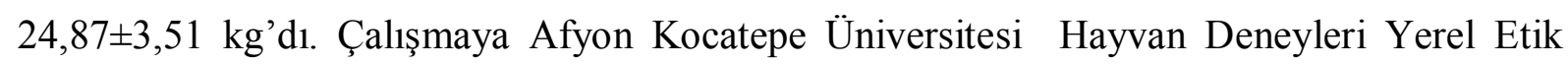
Kurulu (A.K.Ü HADYEK)'nun 21.05.2015 tarih ve 457-15 referans numaralı izni ile başland1.

\section{Anestezik İlaçlar}

Çalışmada kullanılan her iki gruptaki köpeklere preanestezik olarak Midazolam (Dormicum ${ }^{\circledR}$, Roche, İsviçre) uyguland1. Bir gruptaki köpekler $(\mathrm{n}=10)$ indüksiyon ajan1 olarak Ketamin HCl (Alfamine, Ege-Vet, Türkiye), diğer gruptaki köpeklerde $(n=10)$ ise Propofol (Propofol®, Fresenius, İstanbul, Türkiye) ile indüksiyon sağlandı ve anestezi idamesi için İzofloran (Isoflurane-USP, Abbott,İstanbul,Türkiye) kullanıldı. 


\section{Anestezi Protokolü}

Her iki gruptaki köpeklere anestezik madde ve serum uygulamaları için vena sefalica antebrahi'ye $18 \mathrm{G}$ intraket yerleştirildi. MKİ protokolü uygulanan köpeklerde 12 saat açlı̆̆ takiben Preanestezik olarak midazolam 0,2-0,4 $\mathrm{mg} / \mathrm{kg}$ dozda intravenöz yolla uygulandı. Anestezi indüksiyonu Ketamin HCl'ün 15 mg/kg dozda intravenöz uygulanmasıyla sağlandı.

MPİ protokolü uygulanan köpeklerde 12 saat açlığı takiben preanestezik olarak midazolam 0,2-0,4mg/kg dozda intravenöz kullanıldı. Anestezi indüksiyonu; propofol solüsyonunun 6-7 mg/kg dozda intravenöz yolla yavaş şekilde enjekte edilmesiyle sağlandı.

Hemen ardından uygun çaptaki endotrakeal tüplerle entübasyon gerçekleştirildi. Entübasyon için, hayvanın büyüklüğüne göre 7.0 - $9.0 \mathrm{~mm}$ iç çapında balonlu tip tek kullanımlık endotrakeal tüpler kullanıldı. Anestezi cihazının hasta konnektörü, hayvanın trakeasına yerleştirilmiş olan endotrakeal tüpe bağlandı ve spontan solunumu sürmekte olan hayvanın anestezisi İzofloran-oksijen karışımıyla sürdürüldü. Uygulama süresince, vaporizatör \%1 ile \%3 arasında açık tutuldu. Spontan solunumun deprese olmasıyla birlikte, dakikada 12-15 arasında aralıklı pozitif basınç ventilasyonu yaptırıldı ve tidal volüm, 15 $\mathrm{ml} / \mathrm{kg}$ olarak ayarlandı. Her iki grupta i.v yolla replasman solüsyonu olarak $10 \mathrm{ml} / \mathrm{kg} / \mathrm{saat}$ volümde Ringer Laktat infüzyonu gerçekleştirildi.

Çalışmada tüm köpeklerden preoperatif 0. dakika, intraoperatif 15.dakika ve 30 . dakikada hemogram, kan gazı ve koagülasyon parametreleri ölçümü için venöz kan örnekleri alındı ve vital parametreleri kaydedildi. Vücut 1sısı termometre ile ölçüldü. Bütün olguların anesteziden çıkışları kontrol altında gerçekleşti. Hospitalizasyon bokslarına nakledilen köpeklerden postoperatif 0 . ve 6 . saatlerde de kan örnekleri alındı ve vital parametreleri kaydedildi.

\section{İstatistiksel Analizler}

Pıhtılaşma faktörleri, Hemogram parametreleri, biyokimyasal parametreler ve kan gazı parametrelerinde grup içinde zamana göre farklılıkların değerlendirilmesinde tekrarlı ölçümler ANOVA testi uygulandı. Gruplar arasında farklılıkların belirlenmesinde bağımsız örneklemler t-testi kullanıldı. Veriler ortalama \pm standart sapma olarak gösterildi. Önemlilik derecesi $\mathrm{p}<0,05$ olan değerler istatistiksel olarak anlamlı kabul edildi. 
Köpeklerde Midazolam-Ketamin-İzofloran ve Midazolam-Propofol-İzofloran Anestezisinin Koagulasyon Parametrelerine Etkisinin Araştırılması

Evaluation of the Effects of Midazolam-Ketamine-Isoflurane and Midazolam-Propofol- Isoflurane Anesthesia on Coagulation Parameters in Dogs.

Tablo 1: Araştırmaya dahil edilen olgulara ait kayıt verileri

\begin{tabular}{|c|c|c|c|c|c|c|c|}
\hline Olgu No & Operasyon Adı & $\begin{array}{l}\text { Operasyon } \\
\text { Süresi (dk) }\end{array}$ & Irk & Yaş & Cinsiyet & $\begin{array}{l}\text { Canlı } \\
\text { Ağırlık } \\
\text { (kg) }\end{array}$ & $\begin{array}{l}\text { Hastane } \\
\text { Protokol } \\
\text { No }\end{array}$ \\
\hline MKİ - 1 & Ovariohisterektomi & 40 & Golden etriever & 1 yaş & Dişi & 21,2 & 76 \\
\hline MKİ - 2 & Ovariohisterektomi & 35 & Melez & 2 yaş & Dişi & 22,9 & 77 \\
\hline MKİ - 3 & Ovariohisterektomi & 45 & Melez & 5 yaş & Dişi & 23,6 & 78 \\
\hline MKİ - 4 & Ovariohisterektomi & 65 & Melez & 2 yaş & Dişi & 25,1 & 79 \\
\hline MKİ - 5 & Ovariohisterektomi & 60 & Golden etriever & 1,5 yaş & Dişi & 23,1 & 80 \\
\hline MKİ - 6 & Ovariohisterektomi & 45 & Melez & 3 yaş & Dişi & 22,2 & 81 \\
\hline MKİ - 7 & Ovariohisterektomi & 68 & Melez & 3,5 yaş & Dişi & 30,5 & 82 \\
\hline MKİ - 8 & Ovariohisterektomi & 35 & Melez & 5 yaş & Dişi & 31,2 & 85 \\
\hline MKİ - 9 & Ovariohisterektomi & 80 & Melez & 2 yaş & Dişi & 22,3 & 86 \\
\hline MKİ - 10 & Ovariohisterektomi & 42 & Melez & 3 yaş & Dişi & 26,6 & 87 \\
\hline MPİ - 1 & Harder Bezi Prolapsusu & 45 & Kangal & 5 aylık & Erkek & 41,8 & 53 \\
\hline MPİ - 2 & Femur Osteosentez & 75 & Melez & 1 yaş & Erkek & 19,2 & 66 \\
\hline MPİ - 3 & Harder Bezi Prolapsusu & 35 & Pointer & 4 aylık & Erkek & 14 & 67 \\
\hline MPİ - 4 & Femur Osteosentez & 90 & Kangal & 2 yaş & Dişi & 45,7 & 64 \\
\hline MPİ - 5 & Kistik Fibroma & 60 & Rottweiler & 6 yaş & Dişi & 20,6 & 161 \\
\hline MPİ - 6 & Ovariohisterektomi & 75 & Melez & 2,5 yaş & Dişi & 27,8 & 200 \\
\hline MPİ - 7 & Ovariohisterektomi & 45 & Rottweiler & 5 yaş & Dişi & 19 & 45 \\
\hline MPİ - 8 & Ovariohisterektomi & 40 & Melez & 1 yaş & Dişi & 16,5 & 46 \\
\hline MPİ - 9 & Femur Osteosentez & 77 & Melez & 4 yaş & Dişi & 17,3 & 201 \\
\hline MPİ - 10 & Ovariohisterektomi & 42 & Golden etriever & 4 yaş & Dişi & 30,9 & 72 \\
\hline
\end{tabular}

\section{Bulgular}

$\mathrm{Bu}$ çalışmada Midazolam-Ketamin-İzofloran ( $\mathrm{n}=10)$ Midazolam-Propofol -İzofloran $(\mathrm{n}=10)$ gruplarında preoperatif 0 . dakika, intraoperatif 15 . ve 30. dakika, postoperatif 0. dakika ve 6. saatlerde demografik veriler (yaş, canlı ağırlık, operasyon süresi) ölçülmüş olup Tablo 2 de verilmiştir.

Tablo 2: MKİ ( $\mathrm{n}=10)$ ve MPİ ( $\mathrm{n}=10)$ Gruplarının bazı demografik sonuçları (Ort $\pm \mathrm{SS})$.

\begin{tabular}{llll}
\hline GRUP & YAŞ & CANLI AĞIRLIK (kg) & OPERASYON SÜRESİ (dk) \\
\hline MKI & $2,45 \pm 1,64$ & $24,69 \pm 10,85$ & $61,2 \pm 17,95$ \\
MPİ & $2,8 \pm 1,38$ & $24,87 \pm 3,51$ & $51 \pm 16,25$ \\
\hline
\end{tabular}

$\mathrm{Bu}$ çalışmada Midazolam-Ketamin-İzofloran (n=10) Midazolam-Propofol -İzofloran $(n=10)$ gruplarında preoperatif 0 . dakika, intraoperatif 15 . ve 30. dakika, postoperatif 0 . dakika ve 6. saatlerde vital parametreler (solunum, kalp frekansı, vücut 1sıs1) ölçülmüş olup Tablo 3.de verilmiştir. 
Köpeklerde Midazolam-Ketamin-İzofloran ve Midazolam-Propofol-İzofloran Anestezisinin Koagulasyon Parametrelerine Etkisinin Araştırılması

Evaluation of the Effects of Midazolam-Ketamine-Isoflurane and Midazolam-Propofol- Isoflurane Anesthesia on Coagulation Parameters in Dogs.

Tablo 3: MKİ $(n=10)$ ve MPİ ( $n=10)$ Gruplarında vital parametrelerinin zamana göre değişimi (Ort \pm SS).

\begin{tabular}{|c|c|c|c|}
\hline ZAMAN - GRUP & $\begin{array}{l}\text { SOLUNUM } \\
\text { (dk) }\end{array}$ & $\begin{array}{l}\text { KALP FREKANSI } \\
\text { (atım/dk) }\end{array}$ & $\begin{array}{l}\text { VÜCUT ISISI } \\
\left({ }^{\circ} \mathbf{C}\right)\end{array}$ \\
\hline \multicolumn{4}{|l|}{ 0. DK } \\
\hline MKİ & $19,5 \pm 1,84$ & $110,1 \pm 10,33$ & $38,77 \pm 0,19$ \\
\hline MPİ & $20,7 \pm 3,43$ & $144 \pm 20,1$ & $38,83 \pm 0,18$ \\
\hline \multicolumn{4}{|l|}{ 15. DK } \\
\hline MKİ & $15 \pm 0$ & $110,5 \pm 10,41$ & $38,76 \pm 0,23$ \\
\hline MPİ & $15 \pm 0$ & $136,5 \pm 18,36$ & $38,8 \pm 0,18$ \\
\hline \multicolumn{4}{|l|}{ 30. DK } \\
\hline MKİ & $15 \pm 0$ & $107,8 \pm 12,02$ & $38,82 \pm 0,11$ \\
\hline MPÍ & $15 \pm 0$ & $130,9 \pm 18,4$ & $38,8 \pm 0,16$ \\
\hline \multicolumn{4}{|l|}{ Post Op. 0. DK } \\
\hline MKİ & $15 \pm 2,53$ & $104,9 \pm 13,22$ & $38,83 \pm 0,16$ \\
\hline MPİ & $16,2 \pm 2,62$ & $121,7 \pm 11,98^{*}$ & $38,88 \pm 0,16$ \\
\hline \multicolumn{4}{|l|}{ Post Op. 6. SAAT } \\
\hline MKİ & $20 \pm 2,26$ & $102,6 \pm 9,66$ & $38,88 \pm 0,10$ \\
\hline MPİ & $18,3 \pm 2,41$ & $119,2 \pm 3,79 * *$ & $38,97 \pm 0,34$ \\
\hline
\end{tabular}

Bu çalışmada Midazolam-Ketamin-İzofloran ( $\mathrm{n}=10)$ Midazolam-Propofol -İzofloran $(\mathrm{n}=10)$ gruplarında preoperatif 0 . dakika, intraoperatif 15 . ve 30. dakika, postoperatif 0 . dakika ve 6. saatlerde koagülasyon parametreleri (PT, TT, Fibrinojen, APTT) ölçülmüş olup Tablo 4.de verilmiştir.

Tablo 4: MKİ (n=10) ve MPİ ( $\mathrm{n}=10)$ gruplarında zamana göre koagülasyon parametreleri ölçümleri (Ort \pm SS).

\begin{tabular}{|c|c|c|c|c|}
\hline ZAMAN - GRUP & PT (saniye) & TT (saniye) & $\begin{array}{l}\text { FİBRİNOJEN } \\
(\mathrm{mg} / \mathrm{dl})\end{array}$ & APTT (saniye) \\
\hline \multicolumn{5}{|l|}{ 0. DK } \\
\hline MKİ & $9,97 \pm 1,35$ & $10,08 \pm 3,33$ & $584,5 \pm 295,7$ & $15,82 \pm 3,76$ \\
\hline MPI & $10,42 \pm 2,83$ & $11,33 \pm 3,93$ & $508,8 \pm 214,34$ & $15,64 \pm 5,81$ \\
\hline \multicolumn{5}{|l|}{ 15. DK } \\
\hline MKİ & $8,93 \pm 1,92$ & $9,98 \pm 3,68$ & $538,9 \pm 284,51$ & $14,13 \pm 4,82$ \\
\hline MPİ & $9,87 \pm 2,62$ & $11,22 \pm 3,3$ & $408,5 \pm 236,86$ & $20,45 \pm 20,28$ \\
\hline \multicolumn{5}{|l|}{ 30. DK } \\
\hline MKİ & $8,82 \pm 2,46$ & $11,07 \pm 4,03$ & $475,8 \pm 274,84$ & $14,74 \pm 3,67$ \\
\hline MPİ & $12,08 \pm 6,89$ & $10,04 \pm 3,15$ & $481 \pm 245,68$ & $15,38 \pm 7,05$ \\
\hline \multicolumn{5}{|l|}{ Post Op. 0. DK } \\
\hline MKİ & $10,84 \pm 4,4$ & $10,49 \pm 3,23$ & $434,4 \pm 304,26$ & $12,34 \pm 5,68$ \\
\hline MPİ & $8,95 \pm 2,33$ & $15,12 \pm 8,24$ & $563,3 \pm 287,04$ & $20,13 \pm 11,3$ \\
\hline \multicolumn{5}{|l|}{ Post Op. 6. SAAT } \\
\hline MKİ & $9,54 \pm 3,07$ & $9,81 \pm 3,94$ & $396,2 \pm 251,07$ & $13,54 \pm 4,66$ \\
\hline MPI & $12,57 \pm 6,78$ & $15,06 \pm 12,73$ & $377,8 \pm 205,66$ & $15,86 \pm 10,87$ \\
\hline
\end{tabular}

Bu çalışmada Midazolam-Ketamin-İzofloran ( $\mathrm{n}=10)$ Midazolam-Propofol -İzofloran $(\mathrm{n}=10)$ gruplarında preoperatif 0 . dakika, intraoperatif 15 . ve 30. dakika, postoperatif 0. 
Köpeklerde Midazolam-Ketamin-İzofloran ve Midazolam-Propofol-İzofloran Anestezisinin Koagulasyon Parametrelerine Etkisinin Araştırılması

Evaluation of the Effects of Midazolam-Ketamine-Isoflurane and Midazolam-Propofol- Isoflurane Anesthesia on Coagulation Parameters in Dogs.

dakika ve 6. saatlerde hemogram parametreleri (WBC, lenfosit, monosit, granülasit, lenfosit $\%$, monosit \%, granülosit \%, RBC, MCV, MCH, MCHC, RDW, PLT, MPV, PDW, PCT, eozinofil \%) ölçülmüş olup Tablo 5.a., Tablo 5.b. ve Tablo 5.c de verilmiştir.

Tablo 5.a: MKİ ( $\mathrm{n}=10)$ ve MPI ( $\mathrm{n}=10)$ Gruplarında hemogram sonuçlarının zamana göre değişimi (Ortalama \pm Standart Sapma).

\begin{tabular}{|c|c|c|c|c|c|c|}
\hline ZAMAN - GRUP & $\begin{array}{l}\mathrm{WBC} \\
\left(10^{9} / \mathrm{L}\right)\end{array}$ & $\begin{array}{l}\text { LENFOSIT } \\
\left(10^{9} / \mathrm{L}\right)\end{array}$ & $\begin{array}{l}\text { MONOSIT } \\
\left(10^{9} / \mathrm{L}\right)\end{array}$ & $\begin{array}{l}\text { GRANÜLOSIT } \\
\left(10^{9} / \mathrm{L}\right)\end{array}$ & $\begin{array}{l}\text { LENFOSIT } \\
\%(\%)\end{array}$ & $\begin{array}{l}\text { MONOSIT } \\
\%(\%)\end{array}$ \\
\hline \multicolumn{7}{|l|}{ 0. DK } \\
\hline MKİ & $11,88 \pm 3,79$ & $4,44 \pm 7,49$ & $0,53 \pm 0,42$ & $11,91 \pm 8,37$ & $19,35 \pm 11,48$ & $3,48 \pm 1,44$ \\
\hline MPİ & $19,97 \pm 9,4$ & $2,12 \pm 1,77$ & $0,53 \pm 0,29$ & $17,32 \pm 7,52$ & $9,74 \pm 3,13$ & $2,75 \pm 0,95$ \\
\hline \multicolumn{7}{|l|}{ 15. DK } \\
\hline MKİ & $11,66 \pm 3,7$ & $2,16 \pm 1,55$ & $0,42 \pm 0,16$ & $9,08 \pm 2,57$ & $17,18 \pm 8,8$ & $3,49 \pm 0,78$ \\
\hline MPÍ & $15,69 \pm 7,75$ & $1,62 \pm 1,31$ & $0,47 \pm 0,27$ & $13,6 \pm 6,28$ & $9,58 \pm 2,69$ & $3,18 \pm 0,99$ \\
\hline \multicolumn{7}{|l|}{ 30. DK } \\
\hline MKİ & $10,52 \pm 7,55$ & $2,41 \pm 3,9$ & $0,37 \pm 0,18$ & $7,74 \pm 3,87$ & $17,44 \pm 11,86$ & $4,09 \pm 1,81$ \\
\hline MPİ & $13,38 \pm 7,1$ & $1,27 \pm 0,8$ & $0,42 \pm 0,21$ & $11,69 \pm 6,2$ & $9,28 \pm 2,18$ & $3,27 \pm 1,14$ \\
\hline \multicolumn{7}{|l|}{ Post Op. 0. DK } \\
\hline MKİ & $8,96 \pm 4,29 *$ & $1,55 \pm 1,93$ & $0,31 \pm 0,15$ & $7,1 \pm 3,23$ & $15,41 \pm 10,52$ & $4 \pm 1,73$ \\
\hline MPİ & $14,17 \pm 5,86$ & $1,34 \pm 0,63$ & $0,41 \pm 0,18$ & $12,42 \pm 5,14$ & $9,41 \pm 2,14$ & $2,96 \pm 0,51$ \\
\hline \multicolumn{7}{|l|}{ Post Op. 6. SAAT } \\
\hline MKİ & $11,69 \pm 5,82$ & $1,58 \pm 1,03$ & $0,42 \pm 0,32$ & $9,69 \pm 5,19$ & $14,56 \pm 8,99$ & $3,71 \pm 1,8$ \\
\hline MPİ & $15,56 \pm 7,93$ & $1,57 \pm 0,84$ & $0,46 \pm 0,21$ & $13,53 \pm 7,09$ & $10,1 \pm 2,28$ & $3,2 \pm 1,01$ \\
\hline
\end{tabular}

Tablo 5.b: MKİ ( $\mathrm{n}=10)$ ve MPİ $(\mathrm{n}=10)$ Gruplarında hemogram sonuçlarının zamana göre değişimi (Ortalama \pm Standart Sapma) (devamı).

\begin{tabular}{|c|c|c|c|c|c|c|}
\hline ZAMAN - GRUP & $\begin{array}{l}\text { GRANÜLOSIT \% } \\
(\%)\end{array}$ & $\begin{array}{l}\text { RBC } \\
\left(10^{12} / L\right)\end{array}$ & $\begin{array}{l}\text { MCV } \\
\text { (fL) }\end{array}$ & $\begin{array}{l}\text { MCH } \\
(p g)\end{array}$ & $\begin{array}{l}\text { MCHC } \\
\text { (g/dL) }\end{array}$ & $\begin{array}{l}\text { RDW } \\
(\%)\end{array}$ \\
\hline \multicolumn{7}{|l|}{ 0. DK } \\
\hline MKİ & $77,17 \pm 12,18$ & $6,16 \pm 0,79$ & $70,74 \pm 3,57$ & $23,94 \pm 1,47$ & $33,91 \pm 0,76$ & $12,91 \pm 0,85$ \\
\hline MPİ & $87,51 \pm 3,74$ & $6,08 \pm 0,96$ & $70,42 \pm 3,05$ & $22,74 \pm 1,78$ & $32,37 \pm 2,45$ & $14,76 \pm 1,03$ \\
\hline \multicolumn{7}{|l|}{ 15. DK } \\
\hline MKİ & $79,33 \pm 9,39$ & $5,79 \pm 0,88$ & $72,12 \pm 2,82$ & $24,19 \pm 0,84$ & $33,63 \pm 1$ & $12,63 \pm 1,04$ \\
\hline MPİ & $87,24 \pm 3,3$ & $5,32 \pm 0,82$ & $70,38 \pm 3,56$ & $23,03 \pm 1,32$ & $32,8 \pm 0,68 *$ & $14,34 \pm 1,36$ \\
\hline \multicolumn{7}{|l|}{ 30. DK } \\
\hline MKİ & $78,47 \pm 12,17$ & $5,31 \pm 0,99$ & $71,83 \pm 2,91$ & $24,17 \pm 0,83$ & $33,76 \pm 0,97$ & $12,51 \pm 0,89$ \\
\hline MPİ & $87,45 \pm 2,83$ & $6,17 \pm 2,65$ & $70,65 \pm 3,39$ & $21,03 \pm 6,5$ & $29,79 \pm 9,11 *$ & $14,31 \pm 1,78$ \\
\hline \multicolumn{7}{|l|}{ Post Op. 0. DK } \\
\hline MKİ & $80,59 \pm 10,97$ & $5,25 \pm 0,98$ & $70,74 \pm 3,76$ & $23,97 \pm 1,48$ & $33,94 \pm 0,67$ & $12,86 \pm 0,72$ \\
\hline MPİ & $87,63 \pm 2,33$ & $5,3 \pm 0,63$ & $70,32 \pm 3,28$ & $22,88 \pm 1,2$ & $32,61 \pm 0,77$ & $14,28 \pm 1,6$ \\
\hline \multicolumn{7}{|l|}{ Post Op. 6. SAAT } \\
\hline MKİ & $81,73 \pm 9,98$ & $5,63 \pm 1,11$ & $71,8 \pm 3,01$ & $23,19 \pm 3,7$ & $33,65 \pm 1,66$ & $12,49 \pm 0,85$ \\
\hline MPİ & $86,7 \pm 2,73$ & $5,36 \pm 1,62$ & $70,57 \pm 3,56$ & $22,88 \pm 1,06$ & $32,5 \pm 1$ & $14,1 \pm 1,62$ \\
\hline
\end{tabular}


Köpeklerde Midazolam-Ketamin-İzofloran ve Midazolam-Propofol-İzofloran Anestezisinin Koagulasyon Parametrelerine Etkisinin Araştırılması

Evaluation of the Effects of Midazolam-Ketamine-Isoflurane and Midazolam-Propofol- Isoflurane Anesthesia on Coagulation Parameters in Dogs.

Tablo 5.c: MKİ $(n=10)$ ve MPİ ( $n=10)$ Gruplarında hemogram sonuçlarının zamana göre değişimi (Ortalama \pm Standart Sapma) (devamı).

\begin{tabular}{|c|c|c|c|c|c|}
\hline ZAMAN - GRUP & $\begin{array}{l}\text { PLT } \\
\left(10^{9} / \mathrm{L}\right)\end{array}$ & $\begin{array}{l}\text { MPV } \\
\text { (fL) }\end{array}$ & $\begin{array}{l}\text { PDW } \\
(\%)\end{array}$ & $\begin{array}{l}\text { PCT } \\
(\%)\end{array}$ & $\begin{array}{l}\text { EOZINOFIL\% } \\
(\%)\end{array}$ \\
\hline \multicolumn{6}{|l|}{ 0. DK } \\
\hline MKİ & $277,9 \pm 103,56$ & $8,42 \pm 1,23$ & $16,05 \pm 0,38$ & $0,22 \pm 0,07$ & $5,43 \pm 6,39$ \\
\hline MPİ & $433,8 \pm 159,99$ & $9,04 \pm 0,82$ & $15,93 \pm 0,33$ & $0,38 \pm 0,12$ & $3,88 \pm 3,95$ \\
\hline \multicolumn{6}{|l|}{ 15. DK } \\
\hline MKİ & $268,8 \pm 95,55$ & $8,6 \pm 0,81$ & $16,03 \pm 0,41$ & $0,23 \pm 0,08$ & $8,62 \pm 11,21$ \\
\hline MPİ & $341 \pm 125,35$ & $8,94 \pm 0,83$ & $15,92 \pm 0,12$ & $0,3 \pm 0,1$ & $4,04 \pm 3,87$ \\
\hline \multicolumn{6}{|l|}{ 30. DK } \\
\hline MKİ & $206,7 \pm 134,56$ & $8,56 \pm 0,95$ & $16,03 \pm 0,38$ & $0,18 \pm 0,11$ & $2,75 \pm 1,09$ \\
\hline MPİ & $474 \pm 443,03$ & $9 \pm 1,01$ & $15,95 \pm 0,38$ & $0,3 \pm 0,13$ & $4,03 \pm 3,87$ \\
\hline \multicolumn{6}{|l|}{ Post Op. 0. DK } \\
\hline MKI & $195,3 \pm 111,83$ & $8,44 \pm 0,99$ & $16,12 \pm 0,48$ & $0,16 \pm 0,09$ & $6,89 \pm 11,28$ \\
\hline MPİ & $393,1 \pm 125,12$ & $8,76 \pm 0,96$ & $15,73 \pm 0,24$ & $0,34 \pm 0,09$ & $4,19 \pm 3,66$ \\
\hline \multicolumn{6}{|l|}{ Post Op. 6. SAAT } \\
\hline MKI & $269,6 \pm 148,41$ & $8,51 \pm 1,1$ & $16,1 \pm 0,56$ & $0,22 \pm 0,12$ & $4,2 \pm 6,82$ \\
\hline MPİ & $352,7 \pm 140,43$ & $8,73 \pm 1$ & $15,84 \pm 0,26$ & $0,3 \pm 0,1$ & $3,43 \pm 2,44$ \\
\hline
\end{tabular}

$\mathrm{Bu}$ çalışmada Midazolam-Ketamin-İzofloran ( $\mathrm{n}=10)$ Midazolam-Propofol -İzofloran $(\mathrm{n}=10)$ gruplarında preoperatif 0 . dakika, intraoperatif 15 . ve 30. dakika, postoperatif 0. dakika ve 6. saatlerde kan gazı parametreleri $\left(\mathrm{pH}, \mathrm{PCO}_{2}, \mathrm{HCO}_{3}, \mathrm{BE}\right)$ ölçülmüş olup Tablo 6.da verilmiştir.

Tablo 6: MKİ ( $\mathrm{n}=10)$ ve MPİ ( $\mathrm{n}=10)$ Gruplarında kan gazları analiz sonuçlarının zamana göre değişimi (Ortalama \pm Standart Sapma)

\begin{tabular}{|c|c|c|c|c|c|}
\hline ZAMAN - GRUP & $\begin{array}{l}\text { pH } \\
\left(-\log \left[\mathbf{H}^{+}\right]\right)\end{array}$ & $\begin{array}{l}\mathrm{pCO}_{2} \\
(\mathrm{mmHg})\end{array}$ & $\begin{array}{l}\mathrm{pO}_{2} \\
(\mathrm{mmHg})\end{array}$ & $\begin{array}{l}\mathrm{HCO}_{3^{-}} \\
(\mathrm{mmol} / \mathrm{L})\end{array}$ & $\begin{array}{l}\mathrm{BE} \\
(\mathrm{mmol} / \mathrm{L})\end{array}$ \\
\hline \multicolumn{6}{|l|}{ 0. DK } \\
\hline MKI & $7,34 \pm 0,06$ & $44,34 \pm 9,01$ & $62,2 \pm 31,61$ & $23,93 \pm 3,07$ & $-1,76 \pm 3,31$ \\
\hline MPI & $7,3 \pm 0,07$ & $49,12 \pm 7,75$ & $62,54 \pm 38,03$ & $24,34 \pm 2,59$ & $-2 \pm 3,37$ \\
\hline \multicolumn{6}{|l|}{ 15. DK } \\
\hline MKİ & $7,34 \pm 0,05$ & $42,2 \pm 5,39$ & $85,93 \pm 52,19$ & $22,61 \pm 1,55^{*}$ & $-3,18 \pm 2$ \\
\hline MPİ & $7,3 \pm 0,06$ & $50,53 \pm 7,64$ & $81,8 \pm 42,96$ & $24,51 \pm 1,87$ & $-1,94 \pm 2,17$ \\
\hline \multicolumn{6}{|l|}{ 30. DK } \\
\hline MKİ & $7,31 \pm 0,07$ & $45,26 \pm 11,64$ & $64,36 \pm 22,48$ & $22,62 \pm 1,49$ & $-3,54 \pm 1,47$ \\
\hline MPİ & $7,26 \pm 0,06^{*}$ & $56,01 \pm 10,1^{*}$ & $84,76 \pm 56,84$ & $24,78 \pm 1,65$ & $-2,22 \pm 1,77$ \\
\hline \multicolumn{6}{|l|}{ Post Op. 0. DK } \\
\hline MKI & $7,35 \pm 0,04$ & $41,12 \pm 4,55$ & $56,72 \pm 26,09$ & $22,71 \pm 1,15$ & $-2,84 \pm 1,36$ \\
\hline MPİ & $7,26 \pm 0,07$ & $57,72 \pm 11,27^{*}$ & $62,57 \pm 15,92$ & $25,36 \pm 1,34$ & $-1,75 \pm 1,39$ \\
\hline \multicolumn{6}{|l|}{ Post Op. 6. SAAT } \\
\hline MKİ & $7,35 \pm 0,06$ & $41,77 \pm 4,55$ & $45,94 \pm 12,7$ & $22,88 \pm 1,16$ & $-2,74 \pm 1,91$ \\
\hline MPİ & $7,28 \pm 0,05^{*}$ & $54,12 \pm 9,31 *$ & $53,77 \pm 20,67$ & $25,21 \pm 1,58$ & $-1,53 \pm 1,45$ \\
\hline
\end{tabular}

$\mathrm{Bu}$ çalışmada Midazolam-Ketamin-İzofloran ( $\mathrm{n}=10)$ Midazolam-Propofol -İzofloran $(\mathrm{n}=10)$ gruplarında preoperatif 0 . dakika, intraoperatif 15. ve 30. dakika, postoperatif 0 . 
Köpeklerde Midazolam-Ketamin-İzofloran ve Midazolam-Propofol-İzofloran Anestezisinin Koagulasyon Parametrelerine Etkisinin Araştırılması

Evaluation of the Effects of Midazolam-Ketamine-Isoflurane and Midazolam-Propofol- Isoflurane Anesthesia on Coagulation Parameters in Dogs.

dakika ve 6. saatlerde biyokimyasal parametreler (glikoz, laktat, kreatinin, sodyum, potasyum, klor, kalsiyum, hematokrit, hemoglobin) ölçülmüş olup Tablo 7'de verilmiştir.

Tablo 7: MKİ (n=10) ve MPİ ( $\mathrm{n}=10)$ Gruplarında biyokimyasal parametrelerin zamana göre değişimi (Ortalama \pm Standart SS).

\begin{tabular}{|c|c|c|c|c|c|c|c|c|c|}
\hline ZAMAN - GRUP & $\begin{array}{c}\text { GLU } \\
(\mathrm{mg} / \mathrm{dL})\end{array}$ & $\begin{array}{c}\text { LAC } \\
(\mathrm{mmol} / \mathrm{L})\end{array}$ & $\begin{array}{c}\text { CREA } \\
(\mathrm{mg} / \mathrm{dL})\end{array}$ & $\begin{array}{c}\mathrm{Na}^{+} \\
(\mathrm{mmol} / \mathrm{L})\end{array}$ & $\begin{array}{c}\mathbf{K}^{+} \\
(\mathrm{mmol} / \mathrm{L})\end{array}$ & $\begin{array}{c}\mathrm{CL}^{-} \\
(\mathrm{mmol} / \mathrm{L})\end{array}$ & $\begin{array}{c}\mathrm{Ca}^{++} \\
(\mathrm{mmol} / \mathrm{L})\end{array}$ & $\begin{array}{c}\text { HCT } \\
(\%)\end{array}$ & $\begin{array}{c}\text { HB } \\
(\mathrm{g} / \mathrm{dL})\end{array}$ \\
\hline $\begin{array}{l}\text { 0. DK } \\
\text { MKİ } \\
\text { MPİ }\end{array}$ & $\begin{array}{l}120 \pm 23,75 \\
109,3 \pm 22,4\end{array}$ & $\begin{array}{l}2,4 \pm 0,88 \\
2,15 \pm 0,85\end{array}$ & $\begin{array}{l}0,85 \pm 0,23 \\
0,83 \pm 0,22\end{array}$ & $\begin{array}{l}144,5 \pm 2,54 \\
148,1 \pm 5,85\end{array}$ & $\begin{array}{l}4,11 \pm 0,24 \\
4,15 \pm 0,34\end{array}$ & $\begin{array}{l}115,4 \pm 3,13 \\
115,2 \pm 2,61\end{array}$ & $\begin{array}{l}1,29 \pm 0,08 \\
1,3 \pm 0,14\end{array}$ & $\begin{array}{l}40,6 \pm 8,73 \\
40,1 \pm 7,92\end{array}$ & $\begin{array}{l}13,8 \pm 3 \\
13,62 \pm 2,74\end{array}$ \\
\hline $\begin{array}{l}\text { 15. DK } \\
\text { MKİ } \\
\text { MPİ }\end{array}$ & $\begin{array}{l}111,6 \pm 31 \\
154,1 \pm 72,8\end{array}$ & $\begin{array}{l}2,28 \pm 0,76 \\
2,54 \pm 0,72 \\
\end{array}$ & $\begin{array}{l}0,92 \pm 0,24 \\
0,83 \pm 0,22 \\
\end{array}$ & $\begin{array}{l}146,9 \pm 3,9 \\
145,7 \pm 3,83\end{array}$ & $\begin{array}{l}3,92 \pm 0,32 \\
4,19 \pm 0,23 \\
\end{array}$ & $\begin{array}{l}116,4 \pm 4,5 \\
114,3 \pm 3,27\end{array}$ & $\begin{array}{l}1,26 \pm 0,1 \\
1,26 \pm 0,16 \\
\end{array}$ & $\begin{array}{l}35,9 \pm 5,24 \\
36,5 \pm 4,58 \\
\end{array}$ & $\begin{array}{l}12,22 \pm 1,74 \\
12,38 \pm 1,58 \\
\end{array}$ \\
\hline $\begin{array}{l}\text { 30. DK } \\
\text { MKİ } \\
\text { MPİ }\end{array}$ & $\begin{array}{l}127,5 \pm 46 \\
153,1 \pm 58,66 \\
\end{array}$ & $\begin{array}{l}2,52 \pm 0,77 \\
2,74 \pm 0,77 \\
\end{array}$ & $\begin{array}{l}0,89 \pm 0,21 \\
0,9 \pm 0,2\end{array}$ & $\begin{array}{l}145,4 \pm 4,17 \\
145 \pm 2\end{array}$ & $\begin{array}{l}3,97 \pm 0,33 \\
4,1 \pm 0,82 \\
\end{array}$ & $\begin{array}{l}115,7 \pm 2,83 \\
112,7 \pm 2,9 \\
\end{array}$ & $\begin{array}{l}1,23 \pm 0,17 \\
1,34 \pm 0,08 \\
\end{array}$ & $\begin{array}{l}37,3 \pm 8,38 \\
35,9 \pm 3,72\end{array}$ & $\begin{array}{l}12,66 \pm 2,85 \\
12,21 \pm 1,27\end{array}$ \\
\hline $\begin{array}{l}\text { Post Op. 0. DK } \\
\text { MKİ } \\
\text { MPİ }\end{array}$ & $\begin{array}{l}126,6 \pm 35,14 \\
145,2 \pm 45,33 \\
\end{array}$ & $\begin{array}{l}2,65 \pm 0,61 \\
2,44 \pm 0,73 \\
\end{array}$ & $\begin{array}{l}0,86 \pm 0,14 \\
0,86 \pm 0,22 \\
\end{array}$ & $\begin{array}{l}145,6 \pm 4,17 \\
145,4 \pm 1,78 \\
\end{array}$ & $\begin{array}{l}3,97 \pm 0,37 \\
4,07 \pm 0,23 \\
\end{array}$ & $\begin{array}{l}115,2 \pm 3,04 \\
113,5 \pm 2,17\end{array}$ & $\begin{array}{l}1,26 \pm 0,13 \\
1,36 \pm 0,09 \\
\end{array}$ & $\begin{array}{l}37,5 \pm 8,66 \\
36,7 \pm 4,22 \\
\end{array}$ & $\begin{array}{l}12,71 \pm 2,88 \\
12,43 \pm 1,43 \\
\end{array}$ \\
\hline $\begin{array}{l}\text { Post Op. } 6 . \\
\text { SAAT } \\
\text { MKİ } \\
\text { MPİ }\end{array}$ & $\begin{array}{l}125,4 \pm 16,72 \\
136,2 \pm 35,35\end{array}$ & $\begin{array}{l}2,8 \pm 0,53 \\
2,81 \pm 0,6\end{array}$ & $\begin{array}{l}0,83 \pm 0,16 \\
0,9 \pm 0,2\end{array}$ & $\begin{array}{l}144,9 \pm 3,18 \\
145,1 \pm 1,85\end{array}$ & $\begin{array}{l}3,97 \pm 0,37 \\
3,98 \pm 0,32\end{array}$ & $\begin{array}{l}115,5 \pm 2,68 \\
113,4 \pm 1,84\end{array}$ & $\begin{array}{l}1,29 \pm 0,1 \\
1,32 \pm 0,07\end{array}$ & $\begin{array}{l}37,2 \pm 9,54 \\
38,3 \pm 4,94\end{array}$ & $\begin{array}{l}12,6 \pm 3,17 \\
12,98 \pm 1,76\end{array}$ \\
\hline
\end{tabular}

\section{Tartışma ve Sonuç}

$\mathrm{Bu}$ araştırmada, köpeklerde farklı operatif girişimlerde uygulanan MidazolamKetamin-İzofloran (MKİ) ve Midazolam-Propofol-İzofloran (MPİ) anestezisinin koagülasyon parametreleriyle birlikte biyokimyasal, hematolojik parametreler ve kan gazları üzerine olan etkilerinin karşılaştırılması amaçlanmıştır.

Cerrahi operasyon sırasında yeterli bir hemostaz gereklidir. Bu nedenle genel anestezi sırasında kullanılan ilaçların hemostaz ve fibrinolizis üzerindeki etkileri önemli bir klinik durumdur. İdeal anestetik koagülasyon işlevleriyle çelişmemelidir (Aydilek, 2007). İnsanlarda yapılan bir çalışma olan Munro ve arkadaşlarının (1997) yaptığ asemptomatik bireylerde preoperatif olarak yapılan testlerde trombosit sayısındaki bozukluk görülme oranının $\% 1,1$ den düşük olduğu, $\% 0,4-4,8$ oranında protrombin zamanı $(\mathrm{PT}), \% 0$ 15,6 oranında ise aktive parsiyel tromboplastin zamanı (aPTT) uzaması bulunduğunu bildirmişlerdir.

Protrombin zamanı (PT), başlangıç doku faktörleri ve fosfolipid kombinasyonu için kullanılır ve primer olarak ekstrinsik ve ortak koagülasyon yolunu değerlendirmek için ölçülür (Brainard, 2015). Bu testte plazman kalsiyum ve protromboplastin (doku faktörü) eklenerek ekstrinsik yoldan fibrin pıhtısı oluşana kadar geçen süre ölçülür. Ekstrinsik yolda 
bulunan faktör VII ile ortak yolda bulunan faktör X, V, protrombin ve fibrinojen düzeylerinin normal olması durumunda PT normal olarak ölçülür. Bu faktörlerin normalin \%10'dan aşağısına düşene kadar PT uzaması gözlenmez. Tek başına PT uzaması kalıtsal nedenlerden sadece faktör VII eksikliğinde görülür. Karaciğer hastalığı, vitamin K eksikliği ve faktör VII'ye karşı inhibitör varlığında da PT uzaması görülür (Rodges ve Bitthel, 1999). Chohan ve ark., (2011) yaptıkları bir araştırmada, PT'nin başlangıç değerini 7,8 $0,8(6,7-9,1)$ saniye olduğunu bildirmiştir. Van Lue ve ark., (2007) ise; minör cerrahi girişim yapılan ve propofol indüksiyonu sonunda izofloranla genel anestezi uyguladıkları köpeklerin venöz kan

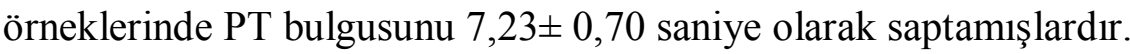

Bu araştırmada PT ölçümleri Tüm ölçüm zamanlarında gruplar arasında belirlenen bulgular istatistiksel olarak karşılaştırıldığında anlamsız $(\mathrm{P}>0,05)$ bulunmuştur. Gerçekleştirilen bu araştırmada, her iki anestezi kombinasyonunda ölçülen PT başlangıç değerinin, intraoperatif ve postoperatif ölçümlerle karşılaştırıldığında önemli bir değişimin belirlenmemiş olması literatür ile paralellik göstermektedir.

Trombin zamanı (TT) uzun bulunduğunda afibrinojenemi, hipofibrinojemi ve disfibrinojemi gibi kalıtsal nedenlerin yanı sıra heparin tedavisi veya kontaminasyonu, yaygın damar içi pıhtılaşma gibi edinsel nedenler araştırılmalıdır (Seligsohn ve Coller, 2001). APTT ile eş değerdedir, fakat güvenirliliği daha azdır. Fibrinojenin fibrine dönüşümünü ölçmektedir (Aktaş ve ark., 2005). Van Lue ve ark., (2007) venöz kan örneklerinde TT bulgusunu $11,34 \pm 1,49$ saniye olarak saptamışlardır.

$\mathrm{Bu}$ araştırmada tüm ölçüm zamanlarında gruplar arasında belirlenen bulgular istatistiksel olarak karşılaştırıldığında anlamsız $\quad(\mathrm{P}>0,05)$ bulunmuştur. Her iki gruptaki preoperatif TT değerlerinin intraoperatif ve postoperatif değerler karşılaştırıldığında anlamlı bir değişimin olmadığ olduğu belirlenmiştir.

Fibrinojen karaciğer parankim hücrelerinde oluşur. Eriyebilen bir plazma proteinidir. Trombin tarafindan erimeyen fibrine dönüştürülür. Serumda bulunmaz. Molekül ağırlığ1 380.000 daltondur (Yılmaz, 2000). Trombin zamanı kan fibrinojen düzeyine bağlıdır ve ortak yolda sadece fibrin oluşumuyla ölçülür (Brainard, 2015). Van Lue ve arkadaşları (2007), 


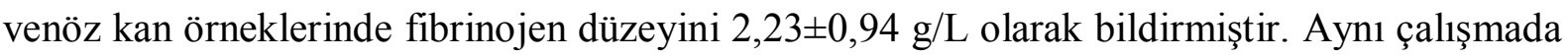
arteriyel kandaki fibrinojen düzeyinin azaldığg ve TT'nin uzadığı bildirilmiştir.

$\mathrm{Bu}$ araştırmada Fibrinojen düzeyi için tüm ölçüm zamanlarında gruplar arasında belirlenen bulgular istatistiksel olarak karşılaştırıldığında anlamsız $(P>0,05)$ bulunmuştur.

Her iki gruptaki ölçüm zamanlarında elde edilen sonuçlar göz önüne alındığında bulguların normal sınırlarda olduğu; söz konusu iki anestezi kombinasyonunun plazminojen düzeyine olumsuz etkisinin olmadığı ve bu verilerin literatürle paralellik gösterdiği, diğer yandan TT dikkate alındığında; ölçüm zamanındaki sonuçlar dikkate alındığında TT nin de normal sınırlarda değişti belirlenmiştir. Bu yönüyle de söz konusu bildirimden farklılık göstermektedir. $\mathrm{Bu}$ durum da, bahsi geçen araştırmada premedikasyonda acepromazin kullanılmasının etkisi olduğunu düşündürmektedir.

APTT; intrinsik (Faktör XII, XI, IX, ve VIII) faktörleri ve ortak koagülasyon yolunu ölçmek için kullanılır (Chohan ve ark., 2011). APTT ölçümü sırasında plazmaya fosfolipid, kalsiyum ve ellagic asit veya kaolin gibi bir aktivatör eklenerek intrinsik yoldan fibrin pihtısı oluşana kadar geçen süre ölçülür. Pıhtılaşma faktörlerinin düzeyi normalin \%15-30’undan daha aşağı düşene kadar APTT uzaması görülmez. Tek başına APTT uzaması kalıtsal faktör VIII, IX, XI veya XII eksikliğinde görülür. Bu faktörlere karşı spesifik veya nonspesifik inhibitör varlığında, heparin tedavisi takibinde ve antifosfolipid antikor varlığında da APTT uzun bulunur. Kanama öyküsü bulunmayıp APTT uzun bulunan hastalarda faktör XII, prekallikrein ve HMWK eksikliği gibi nadir görülen kalıtsal nedenler akla gelmelidir. APTT uzun bulunan hastalarda trombin zamanının uzun bulunması heparin varlığını destekler. PT ve APTT'si normal olup ciddi kanama öyküsü bulunan hastalarda faktör XIII eksikliği olabileceği unutulmaması gerektiği bildirilmiştir (Şencan, 2004).

Sağlıklı köpeklerde APTT düzeyi Chohan ve arkadaşları (2011) tarafindan 11,2 $\pm 0,6$

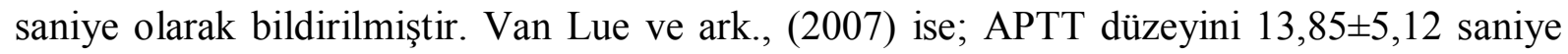
olarak bildirmiştir.

$\mathrm{Bu}$ araştırmada her iki gruptaki ölçüm zamanlarında elde edilen veriler karşılaştırıldığında istatistiksel olarak önemli bir değişim belirlenmemiştir. Ancak yukarıda söz edilen iki araştırma verilerinden bu araştırma preoperatif, intraoperatif ve postoperatif bulguları yüksek bulunmuştur. Elde edilen veriler, bu çalışmaya konu olan Midazolam- 
Ketamin-İzofloran ve Midazolam-Propofol-İzofloran anestezisinin koagülasyon parametrelerine olumsuz etkisinin olmadığını düşündürmektedir.

Gülanber ve arkadaşlarının (2000) köpeklerde medetomidin-ketamin kombinasyonuyla yaptığg bir çalışmada, preoperatif 0 . dakika RBC değeri $6,33 \pm 0,21 \quad 10^{12} / \mathrm{L}$, WBC değeri 13,31 $\pm 0,8810^{9} / \mathrm{L}$ olarak bildirilmiştir. Gülanber ve arkadaşlarının (2001) köpeklerde midazolam-ketamin anestezisiyle yaptı̆̆ 1 başka bir çalışmada ise; preoperatif 0 .

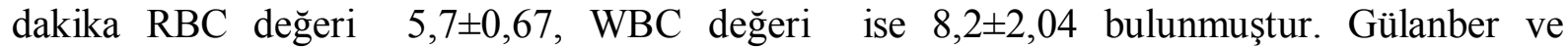
arkadaşlarının (1997) köpeklerde asepromazin-ketamin kombinasyonuyla yaptığı diğer bir çalışmada intraoperatif 15 . dakikadaki RBC değeri $5,83 \pm 0,12$, WBC değeri $10,94 \pm 0,72$ bulunmuştur. Çetinaslan ve Apaydın'ın (2008) köpeklerde medetomidin-ketamin-atipamezol anestezisiyle yaptığ çalışmada, preoperatif 0 . dakika RBC değeri $6,22 \pm 0,18$, WBC değeri 13,66 $\pm 1,27$ olarak bildirmiştir. Diğer yandan Kurtdede ve arkadaşlarının (1994) sağliklı köpeklerde yaptığı bir çalışmada xylazine-ketamin uygulanan ve derin anestezi dönemindeki

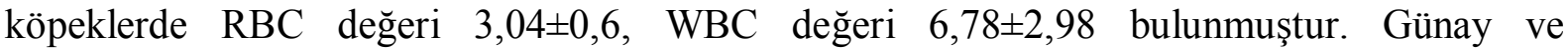
arkadaşlarının (2004) köpeklerde ketamin HCl-midazolam anestezisiyle yaptığı bir çalışmada,

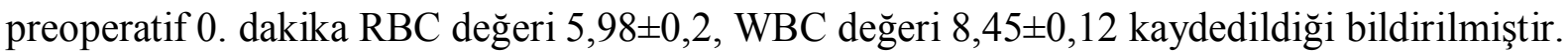
Başka bir anestezi kombinasyonuyla Özaydın ve arkadaşlarının (2001) köpeklerde yaptığı medetomidin-propofol ve ketamin anestezisindeki çalışmasında, preoperatif 0 . dakika dakika RBC değeri 5,7 $\pm 2,6$ olarak bildirilmiştir.

$\mathrm{Bu}$ araştırmada her iki grup bulgulara karşılaştırıldığında intraoperatif 0 . dakika, 15. dakika, 30. dakika ve postoperatif 6. saat ölçümleri anlamsız bulunurken $(\mathrm{P}>0,05)$, MKİ grubundaki postoperatif 0 . dakika ölçümlerindeki düşüş istatistiksel olarak anlamlı $(\mathrm{P}<0,05)$ bulunmuştur.

MKİ grubunda postoperatif 0. dakikada WBC hemodilüsyona bağlı olarak düştügü̈, diğer ölçüm zamanlarındaki değerlerin referans aralıkta olması iki anestezi kombinasyonunu literatür verilerle paralellik gösterdiği sonucuna varılmıştır.

Diğer yandan; $\quad$ RBC sonuçları tüm ölçüm zamanlarında gruplar arasında belirlenen bulgular istatistiksel olarak karşılaştırıldığında anlamsız $(\mathrm{P}>0,05)$ bulunmuştur.

Araştırmada RBC bulgularındaki ve WBC bulgularındaki (MKİ grubu postoperatif 0 . dk hariç) değişim referans aralıkta olmuştur. Söz konusu iki anestezi kombinasyonunun RBC 
ve WBC değerlerine olumsuz etki etmediği kanaatine varılmıştır. $\mathrm{Bu}$ sonuçlarda benzer anestezi kombinasyonlarıyla yapılan çalışmalardaki bulgularla paralellik göstermektedir.

Lenfosit, monosit, granülosit, lenfosit \%, monosit \%, granülosit \%, MCV, $\mathrm{MCH}$, RDW parametrelerinde gruplar arası zamana göre istatistiksel fark gözlenmemiştir ve referans sınırlar içerisinde değişiklik göstermiştir. Bu parametre bulguları dikkate alındığında her iki anestezik kombinasyonun kan tablosuna olumsuz etkisinin olmadığını göstermiştir. Bu bulgu da daha önceki çalışmalarla paralellik göstermektedir.

Gülanber ve arkadaşlarının (2000) köpeklerde medetomidin-ketamin kombinasyonuyla yaptığı bir çalışmada preoperatif 0. dakika PLT değeri 265,4 21,7 bulunmuştur. Gülanber ve arkadaşlarının (2001) köpeklerde midazolam-ketamin anestezisiyle yaptığ 1 başka bir çalışmada preoperatif 0. dakika PLT değeri 287,33 $\pm 57,12$ bulunmuştur. Çetinaslan ve Apaydın'ın (2008) köpeklerde medetomidin-ketamin-atipamezol anestezisiyle

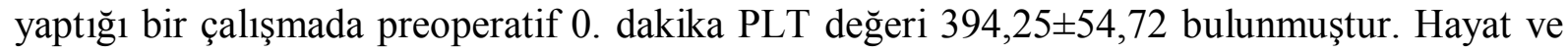
arkadaşlarının (2004) atlarda xylazine-tiletamin-zolazepam-propofol kombinasyonuyla

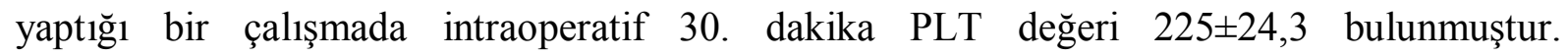

$\mathrm{Bu}$ araştırmada tüm ölçüm zamanlarında gruplar arasında belirlenen bulgular istatistiksel olarak karşılaştırıldığında anlamsız $(\mathrm{P}>0,05)$ bulunmuştur.

Yukarıda bahsedilen araştırmalar dikkate alındığında, gerçekleştirilen bu çalışmada PLT bulgularının referans aralıkta değişmiş olması ve koagülasyon parametrelerindeki değişimin de referans aralıkta olması her ki anestezi kombinasyonunun kan tablosunda sapma olan hastalarda ve koagülasyon problemi olan hastalarda mevcut durumu kötüleştirmeyeceği düşünülmüştür.

MPV, PDW, PCT, eozinofil \% parametrelerinde gruplar arası zamana göre istatistiksel fark gözlenmemiştir ve referans sınırlar içerisinde değişiklik göstermiştir. pH, kandaki hidrojen iyon konsantrasyonu olarak tanımlanır. Hidrojen iyon konsantrasyonundaki artış pH'nın düşmesi anlamına gelir. Kan gazları parametrelerinin değerlendirilmesi hastanın sıvı elektrolit ve asit baz dengesi yönünden prognozuna etki eder. $\mathrm{Bu}$ nedenle anesteziye alınmış hayvanda bu parametreler anestezinin ve operasyonun seyri açısından hekime yol gösterir (Skarada ve ark., 1995). Oskay ve Atalan'ın (2010) sağlıklı köpeklerde medetomidin-propofol-isofluran anestezisiyle yaptığı bir çalışmada preoperatif 0 . 


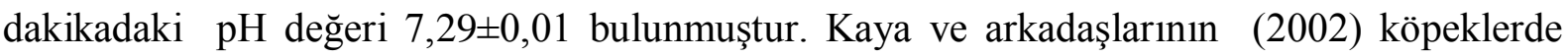

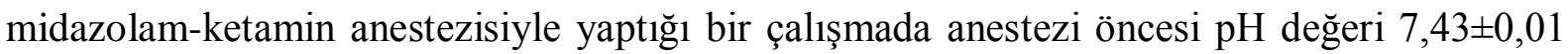
bulunmuştur. Kayhan ve arkadaşlarının (2013) insanlarda yaptığ bir çalışmada sezeryan için anestezi indüksiyonunda ketamin-propofol kombinasyonu (ketofol) kullanılmış olup intraoperatif 15. dakika $\mathrm{pH}$ değeri 7,33 $\pm 0,08$ bulunmuştur. Kurtdede ve arkadaşlarının (1994) sağlıklı köpeklerde yaptığı bir çalışmada xylazine-ketamin uygulanan köpeklerde derin anestezi dönemindeki pH değeri 7,2 $\pm 0,02$ bulunmuştur. Sarıtaş ve arkadaşlarının (2006) sağlıklı köpeklerde yaptığı bir çalışmada propofol anestezisi uygulanmış olup intraoperatif 15. dakikadaki pH değeri 7,38 $\pm 0,02$ bulunmuştur. Kaya ve arkadaşlarının (2002) tavşanlarda

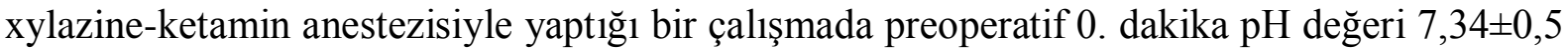
olarak kaydedilmiştir. Apaydın ve Koç’un (2005) köpeklerde izofloran anestezisiyle yaptığ 1

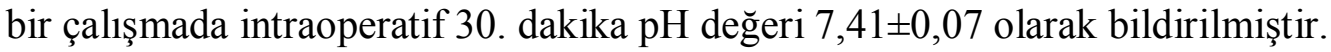

Oskay ve Atalan'ın (2010) sağlıklı köpeklerde medetomidin-propofol-isofluran

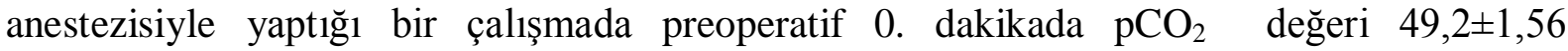
bulunmuştur. Kayhan ve arkadaşlarının (2013) insanlarda yaptığı bir çalışmada sezeryan için anestezi indüksiyonunda ketamin-propofol kombinasyonu (ketofol) kullanılmış olup

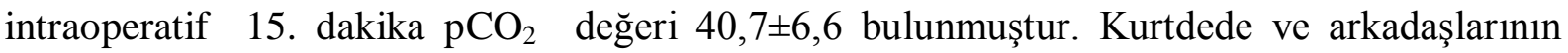
(1994) sağlıklı köpeklerde yaptığı bir çalışmada xylazine-ketamin uygulanan köpeklerde

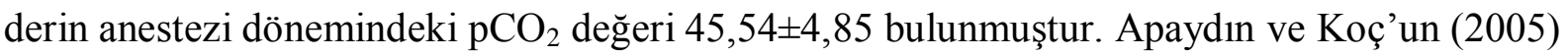
köpeklerde izofloran anestezisiyle yaptığ bir çalışmada intraoperatif 30 . dakika $\mathrm{pCO}_{2}$ değeri $29 \pm 6$ bulunmuştur.

Arteriyel karbondioksit basınç ölçümü, hastanın ventilasyon ile ilgili durumu hakkında bilgi verir. Fizyolojik sınırlar içerisinde kalmasını medüller merkez sağlar. Normal $\mathrm{pCO}_{2} 40$ mmHg'dir (35-45 mm Hg) (Haskins, 1996; Sarıtaş, 1996; Perk, 2000). Eğer $\mathrm{pCO}_{2} 35$ mmHg'den düşük ise hiperventilasyonu gösterir. Aynı zamanda aşırı derecede $\mathrm{CO}_{2}$ eliminasyonu olduğunun da kanıtıdır. Bununla birlikte $\mathrm{pCO}_{2} 44 \mathrm{mmHg}$ 'den büyük ise hipoventilasyonu gösterir. $60 \mathrm{mmHg}$ 'nin üstündeki değerler respiratorik asidozis belirtisidir (Perk, 2000).

$\mathrm{Bu}$ çalışmada $\mathrm{pH}$ ölçüm sonuçları her iki grup bulguları karşılaştırıldığında preoperatif 0 . dakika, intraoperatif 15 . dakika, postoperatif 0 . dakika ve 6 . saat ölçümleri 
anlamsız bulunurken $(\mathrm{P}>0,05)$; intraperatif 30 . dakika ve postoperatif 6 . saat ölçümlerindeki düşüş istatistiksel olarak anlamlı $(\mathrm{P}<0,05)$ bulunmuştur.

Diğer yandan, $\mathrm{pCO}_{2}$ ölçüm sonuçları her iki grup bulguları karşılaştırıldığında preoperatif 0. dakika ölçüm karşılaştırmaları, intraoperatif 15. dakika ölçümleri anlamsız bulunurken $(\mathrm{P}>0,05)$; intraoperatif 30. dakika, postoperatif 0 . dakika ve 6 . saat ölçümlerindeki yükseliş istatistiksel olarak anlamlı $(\mathrm{P}<0,05)$ bulunmuştur.

Araştırmamızda pH'ın MPİ grubunda postoperatif 6. saatteki düşüşü ve $\mathrm{pCO}_{2}$ 'nin yükselmesi dikkate alındığında; MPİ grubundaki köpeklerde respiratovar asidoz geliştiği, bunun da postoperatif hipoventlasyona bağlı olarak ortaya çıktığı düşünülmüştür.

Arteriyel oksijen basınc1, akciğerlerin oksijenizasyon yeteneğinin bir göstergesidir. Akciğer kanının oksijenlenlendirme yeteneğini belirlemek için kullanılır. Ancak tek başına yeterli değildir. Hemoglobin saturasyonu ve oksijen içeriğinin de bilinmesi gerekir (Sarıtaş, 1996; Haskins, 1996). pO pO $_{2}$ lçümü akciğerlerin kanı oksijenlendirme yeteneğini belirlemek için yapılır. Normal $\mathrm{pO}_{2}$ sınırı 90-100 mmHg arasındadır. Bu değer $60 \mathrm{mmHg}$ 'nin altına düştüğünde hipoksemi gelişir. Hipoventilasyona bağlı olarak da hipoksemi gelişebilir. Eğer hipoksemi hipoventilasyona bağlı olarak gelişmiş ise ventilasyon düzeltilerek hipoksemi sağaltılır (Perk, 2000). Akciğerler normal fonksiyonlarıyla alveoler-arteriyel oksijen değişimini düzenleyerek kan $\mathrm{pO}_{2}$ 'sinin normal sınırlarda kalmasını sağlarlar (Haskins, 1996). Oskay ve Atalan'ın (2010) sağlıklı köpeklerde medetomidin-propofol-isofluran anestezisiyle

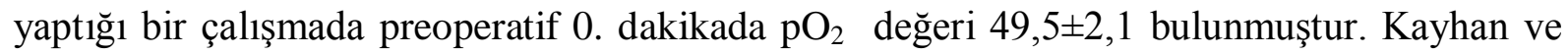
arkadaşlarının (2013) insanlarda yaptığı bir çalışmada sezeryan için anestezi indüksiyonunda ketamin-propofol kombinasyonu (ketofol) kullanılmış olup intraoperatif 15 . dakika $\mathrm{pO}_{2}$

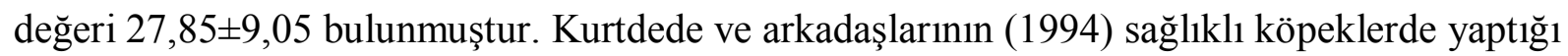
bir çalışmada xylazine-ketamin uygulanan köpeklerde derin anestezi dönemindeki $\mathrm{pO}_{2}$ değeri

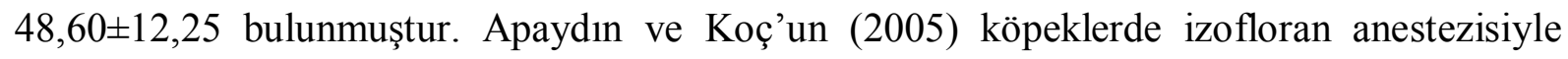
yaptı̆̆ 1 bir çalışmada intraoperatif 30 . dakika $\mathrm{pO}_{2}$ değeri $324 \pm 131 \mathrm{mmHg}$ bulunmuştur.

Çalışmamızda $\mathrm{pO}_{2}$ ölçüm sonuçları tüm ölçüm zamanlarında gruplar arasında belirlenen bulgular istatistiksel olarak karşılaştırıldığında anlamsız $(P>0,05)$ bulunmuştur. 
Araştırmamızda venöz kan örneklerinde $\mathrm{pO}_{2}$ çalışılmıştır. Bununla birlikte MPİ grubu postoperatif 6. saatte $\mathrm{pO}_{2}$ 'nin düşük bulunması $\mathrm{pH}$ ve $\mathrm{pCO}_{2}$ parametrelerinde kaydedilen sonucu destekler niteliktedir.

$\mathrm{HCO}_{3}$ kandaki bikarbonat düzeyini gösterir. Baz açı̆̆ı ve $\mathrm{pH}$ değeriyle birlikte, hastanın metabolik asidoz veya alkaloz yönüyle değerlendirmesinde hekime yardımcı olur (Skarada ve ark., 1995, Haskins, 1996, Sarıtaş, 1996). Kayhan ve arkadaşlarının (2013) insanlarda yaptığ 1 bir çalışmada sezeryan için anestezi indüksiyonunda ketamin-propofol kombinasyonu (ketofol) kullanılmış olup intraoperatif 15. dakika $\mathrm{HCO}_{3}$ değeri 22,61 $\pm 1,55$ bulunmuştur. Kurtdede ve arkadaşlarının (1994) sağlıklı köpeklerde yaptığı bir çalışmada xylazine-ketamin uygulanan köpeklerde derin anestezi dönemindeki $\mathrm{HCO}_{3}$ değeri 21,99 $\pm 2,33$ bulunmuştur. Sarıtaş ve arkadaşlarının (2006) sağlıklı köpeklerde yaptığı bir çalışmada propofol anestezisi uygulanmış olup intraoperatif 15. dakikadaki $\mathrm{HCO}_{3}$ değeri $23,7 \pm 1,1$ olarak kaydedilmiştir. Apaydın ve Koç’un (2005) köpeklerde izofloran anestezisiyle yaptığ1 bir çalışmada intraoperatif 30. dakika $\mathrm{HCO}_{3}$ değeri 17,2 $\pm 3,2$ bulunmuştur.

Baz açığındaki (BE) farklılıklar metabolik değişikliklerle oluşur. Asit baz değişimini gösterir. Genel olarak baz açığı negatif değeri, metabolik asodozisi, pozitif değer ise metabolik alkalozisi gösterir (Skarada ve ark., 1995, Haskins, 1996). Apaydın ve Koç’un (2005) köpeklerde izofloran anestezisiyle yaptığı bir çalışmada intraoperatif 30. dakika BE değeri $-4,5 \pm 3,4$ bulunmuştur. ,

$\mathrm{Bu}$ araştırmada $\mathrm{HCO}_{3}$ ölçüm sonuçları her iki grup bulguları karşılaştırıldığında preoperatif 0 . dakika, intraoperatif 30 . dakika, postoperatif 0 . dakika ve 6 . saat ölçümleri anlamsız bulunurken $(\mathrm{P}>0,05)$; intraoperatif 15 . dakika ölçümündeki düşüş istatistiksel olarak anlamlı $(\mathrm{P}<0,05)$ bulunmuştur.

Yine araştırmamızda kaydedilen Baz açı̆̆ı (BE) tüm ölçüm zamanlarında gruplar arasında belirlenen bulgular istatistiksel olarak karşılaştırıldığında anlamsız $(P>0,05)$ bulunmuştur.

$\mathrm{Bu}$ çalışma ile elde edilen bulgular ışığında gerek MKİ anestezisinin gerekse MPİ anestezisinin kan gazları üzerine mekanik ventilasyonda olumsuz etkisinin olmadığ belirlenmiştir. Her ne kadar MPİ grubunda intraoperatif 15. dakikada Baz açığı bulguları istatistiksel olarak anlamlı bir şekilde düşük bulunsa da intraoperatif 15 . dakikada $\mathrm{pH}$ ve 
$\mathrm{HCO}_{3}$ düzeyinin referans aralıkta olması, asit-baz dengesi yönünden sapmanın olmadığına işaret olarak düşünülmüştür.

Anestezi sırasında karaciğerin normalden fazla glikojen tüketmesine bağlı olarak glikoz düzeyi artar. Oluşan artışta sempatik stimülasyonla hipofize ve adrenokortikal hormonların salgılanmasının artmasının da etkisi olduğu bildirilmektedir. Anestezik ajanlar katekolamin salınımını arttırır. Katekolaminlerde oksijen tüketimini arttıracağından metabolizmanın hızlanacağı, buna bağlı olarakta karaciğer, kalp ve kaslarda glikojenin glikoza çevrilmesinin hızlanacağı bildirilmiştir. Glikoz düzeyinin operasyon öncesi strese bağlı olarak da yükseldiği bildirilmiştir (Hayat, 2001). Köpeklerde normal glikoz düzeyi 60110 mg/dl'dir (Altıntaş ve Fidancı, 1993; Turgut, 2000). Oskay ve Atalan'ın (2010) sağliklı köpeklerde medetomidin-propofol-isofluran anestezisiyle yaptığı bir çalışmada preoperatif 0 . dakikada glikoz değeri 115,5 $\pm 13,2$ bulunmuştur. Çetinaslan ve Apaydın'ın (2008) köpeklerde medetomidin-ketamin-atipamezol anestezisiyle yaptığı bir çalışmada preoperatif 0 . dakika glikoz değeri 92,08 $\pm 6,19$ bulunmuştur. Gülanber ve arkadaşlarının (2000) köpeklerde medetomidin-ketamin kombinasyonuyla yaptığ 1 bir çalışmada, preoperatif 0 . dakika glikoz değeri 90,75 $\pm 0,41$ bulunmuştur. Apaydın ve Koç'un (2005) köpeklerde izofloran anestezisiyle yaptığı bir çalışmada preoperatif 0. dakika glikoz değeri $61 \pm 19$ bulunmuştur.

Bu araştırmada kan glikoz düzeyi ölçüm sonuçları tüm ölçüm zamanlarında gruplar arasında belirlenen bulgular istatistiksel olarak karşılaştırıldığında istatistiksel olarak anlamsız $(\mathrm{P}>0,05)$ bulunmuştur. Her ne kadar iki grup anestezi protokolünde ölçüm zamanlarında kaydedilen glikoz değerlerinde istatistiksel fark olmasa da, özellikle MPÍ grubunda kaydedilen değerler referans değerlerin üstündedir. Bunun da anestezi ve cerrahi strese bağl1 olduğu, dolayısıyla elde edilen bulguların literatür verilerle paralellik gösterdiği düşünülmüştür.

Laktat parametrelerinde gruplar arası zamana göre istatistiksel fark gözlenmemiştir ve referans sınırlar içerisinde değişiklik göstermiştir.

Serum kreatinin konsantrasyonunu etkileyen en önemli nonrenal faktörler muskuler hastalıklardır. Serum kreatinin konsantrasyonundaki artışın en önemli nedeni glomerular filtrasyon hızının azalmasıyla oluşan böbrek hasarıdır (Mazze ve ark., 2000, Karagül ve ark., 2001). Köpeklerde normal serum kreatinin düzeyi, 0,5-1,5 mg/dl'dir (Altıntaş ve Fidanc1, 
1993). Çetinaslan ve Apaydın'ın (2008) köpeklerde medetomidin-ketamin-atipamezol anestezisiyle yaptığ 1 bir çalışmada preoperatif 0 . dakika kreatinin değeri $1,23 \pm 0,16$ olarak kaydedilmiştir. Gülanber ve arkadaşlarının (2000) köpeklerde medetomidin-ketamin kombinasyonuyla yaptığı bir çalışmada preoperatif 0 . dakika kreatinin değeri $0,88 \pm 0,07$ bulunmuştur. Apaydın ve Koç’un (2005) köpeklerde izofloran anestezisiyle yaptığ1 bir çalışmada preoperatif 0 . dakika kreatinin değeri $1,03 \pm 0,32$ bulunmuştur. Araştırmamızda ölçülen kreatinin düzeyi tüm ölçüm zamanlarında gruplar arasında belirlenen bulgular istatistiksel olarak karşılaştırıldığında anlamsız $(P>0,05)$ bulunmuştur. $\mathrm{Bu}$ ölçüm sonuçları referans aralıktadır ve literatürle paralellik göstermektedir.

Apaydın ve Koç’un (2005) köpeklerde izofloran anestezisiyle yaptığı bir çalışmada preoperatif 0 . dakika $\mathrm{Na}^{+}$değeri $139 \pm 6, \mathrm{~K}^{+}$değeri $4,6 \pm 0,5, \mathrm{Cl}^{-}$değeri $103 \pm 8$ bulunmuştur.

$\mathrm{Bu}$ çalışmada ise MKİ grubunda preoperatif 0 . dakika $\mathrm{Na}^{+}$değeri $144,5 \pm 2,54, \mathrm{~K}^{+}$ değeri 4,11 $\pm 0,24, \mathrm{Cl}^{-}$değeri $115,4 \pm 3,13$; MPİ grubunda preoperatif 0 . dakika $\mathrm{Na}^{+}$değeri $148,1 \pm 5,85, \mathrm{~K}^{+}$değeri $4,15 \pm 0,34, \mathrm{Cl}^{-}$değeri $115,2 \pm 2,61$ bulunmuştur. Bu iki çalışma karşılaştırıldığında verilerin birbirine paralellik gösterdiği görülmüştür.

Özaydın ve arkadaşlarının (2001) köpeklerde medetomidin-propofol ve ketamin

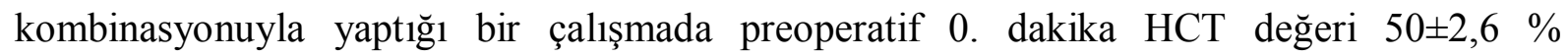
bulunmuştur. Kurtdede ve arkadaşlarının (1994) sağlıklı köpeklerde xylazine-ketamin

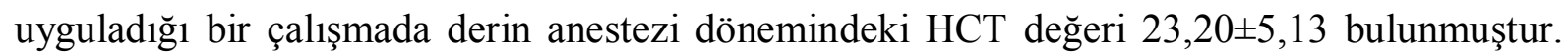

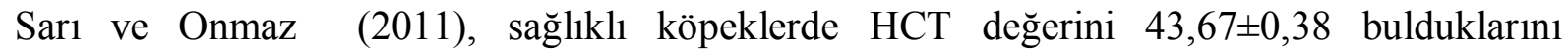
bildirmiştir. Gülanber ve arkadaşları (1997), köpeklerde asepromazin-ketamin

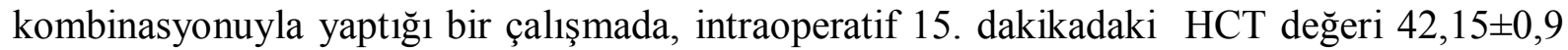
bulunmuştur. Gülanber ve arkadaşları ise (2000), köpeklerde medetomidin-ketamin

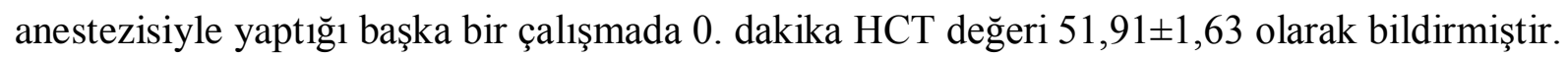
Gülanber ve arkadaşlarının köpeklerde midazolam-ketamin anestezisiyle yaptığ 1 başka bir

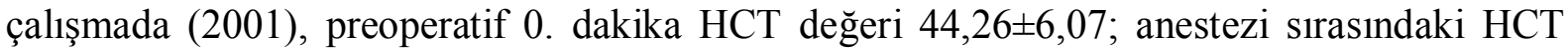
değeri 40,66 $\pm 4,57$ bulunmuştur. Çetinaslan ve Apaydın'ın (2008) köpeklerde medetomidinketamin-atipamezol anestezisiyle yaptığı bir çalışmada preoperatif 0 . dakika HCT değeri 38,26 $\pm 1,44$ olarak kaydedilmiştir. Başka bir araştırmada Günay ve arkadaşları (2004), köpeklerde ketamin HCl-midazolam anestezisinde preoperatif 0. dakika HCT değeri 46,04 $\pm 1,37$ olduğunu bildirmiştir. 
Araştırmamızda HCT ölçüm değerleri tüm ölçüm zamanlarında gruplar arasında belirlenen bulgular istatistiksel olarak karşılaştırıldığında fark belirlenmemiştir $(P>0,05)$.

Yukarıda verilen literatür bilgide HCT değerlerinin sağlıklı köpeklerde farklılık gösterdiğinin altı çizilsede, anestezi çalışmalarında HCT de sapma olmadığı dikkati çekmektedir. Bu noktadan hareketle, araştırmamızda da ölçüm zamanlarında kaydedilen HCT sonuçları referans aralıktadır ve her iki anestezi protokolü HCT üzerine olumsuz etki etmediği kanaatine varılmıştır.

Özaydın ve arkadaşlarının (2001) köpeklerde medetomidin-propofol ve ketamin kombinasyonuyla yaptığı bir çalışmada preoperatif 0 . dakika Hb değeri $15 \pm 0,9$ bulunmuştur. Kurtdede ve arkadaşlarının (1994) sağlıklı köpeklerde xylazine-ketamin uyguladığı bir

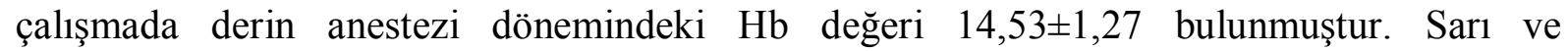
Onmaz(2011)'ın Giardiosis'li ve sağlıklı köpeklerde hematolojik ve biyokimyasal değerlerini

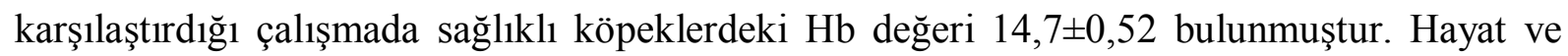
arkadaşlarının (2004) atlarda xylazine-tiletamin-zolazepam-propofol kombinasyonuyla

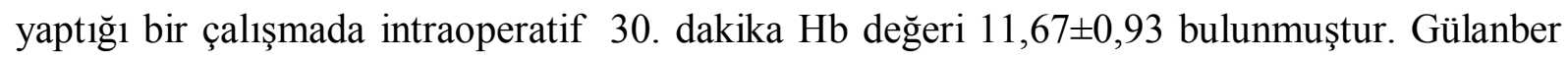
ve arkadaşlarının (1997) köpeklerde asepromazin-ketamin kombinasyonuyla yaptığı bir

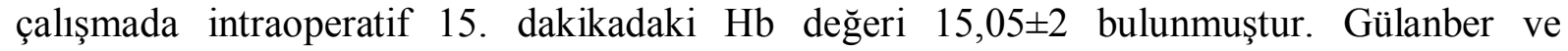
arkadaşlarının (2000) köpeklerde medetomidin-ketamin anestezisiyle yaptığı başka bir

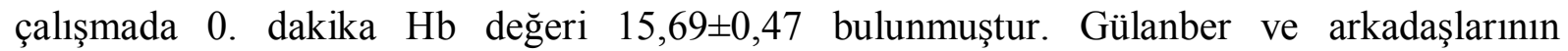
köpeklerde midazolam-ketamin anestezisiyle yaptığı başka bir çalışmada (2001), preoperatif

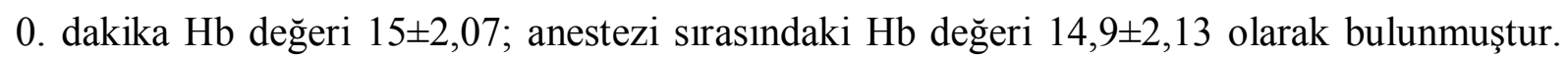
Çetinaslan ve Apaydın'ın (2008) köpeklerde medetomidin-ketamin-atipamezol anestezisiyle yaptığı bir çalışmada preoperatif 0 . dakika $\mathrm{Hb}$ değerini $13,95 \pm 0,55$ olarak kaydettiklerini bildirmiştir. Günay ve arkadaşlarının (2004), köpeklerde ketamin HCl-midazolam

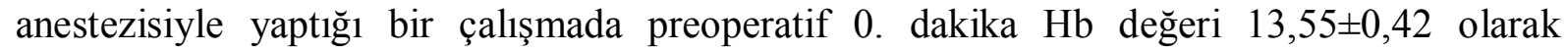
ölçtüklerini bildirmiştir.

$\mathrm{Bu}$ araştırmada $\quad \mathrm{Hb}$ ölçüm sonuçları tüm ölçüm zamanlarında gruplar arasında belirlenen bulgular istatistiksel olarak karşılaştırıldığında anlamsız $(P>0,05)$ bulunmuştur. Araştırmamızda belirlediğimiz $\mathrm{Hb}$ değerleri literatürle paralellik göstermekte olup, iki anestezi protokolünün de preoperatif referans aralıktaki $\mathrm{Hb}$ değerini değiştirmediği ve 
gerçekleştirilen operasyonlarda kanamanın az olmasının da buna kanıt olduğu; bu sonucun da, literatür bilgiyle paralellik gösterdiği saptanmıştır.

Sonuç olarak; bu araştırmada MKİ ve MPİ anestezisinin her ikisinin de koagülasyon bozukluğu olan hastalarda kullanımının durumu kötüleştirmeyeceği ve elde edilen bulgular 1şığında hemogram, kan gazları ve biyokimyasal parametrelerde sapmaya yol açmadığı, dolayısıyla bu verilerin de anesteziklerin güvenirliğini ortaya koyması noktasında önemli bir bulgu olduğu düşünülmüştür. Kliniklerde koagülasyon bozukluğu olan hastalarda söz konusu anestezi protokollerinin başka çalışmalara konu edilmesi, bunun da deneysel çalışmalarla desteklenmesine gerek olduğu sonucuna varılmıştır.

NOT: Bu araştırma makalesi, Afyon Kocatepe Üniversitesi Bilimsel Araştırma Projesi Birimi tarafindan 15-SA.BL.02 nolu proje ile Yüksek Lisans Tez Projesi olarak desteklenmiştir. Aynı adla AKÜ Sağlık Bilimleri Enstitüsü Yüksek Lisans Tezinden özetlenmiştir.

\section{Kaynaklar}

1. Aktaş G, Ayözgen Ş, Tuncalı B. 2005. Öğrenci Ders Notları. Anestezi ve Reanimasyon A.B.D. Dokuz Eylül Üniversitesi Tıp Fakültesi. İZMIR

2. Altıntaş A, Fidancı UR. 1993. Evcil Hayvanlarda ve İnsanda Kanın Biyokimyasal Normal Değerleri, Ankara Üniversitesi Veteriner Fakültesi Dergisi, 40 (2): 173-186.

3. Apaydın N, Koç B. 2005. Köpeklerde İsoflurane ve Sevoflurane Anestezisinin Hemodinamik ve Biyokimyasal Parametrelere Olan Etkilerinin Karşılaştırılması. Veteriner Cerrahi Dergisi. 11 (1-2-3-4): 31-35.

4. Aydilek N, Ceylan C, İpek H, Gündoğdu Ü. 2007. Effects of Xylazine-Diazepam-Ketamine and Xylazine-Tiletamine-Zolazepam Anesthesia on Some Coagulation Parameters in Horses. Yüzüncü Y1l Üniversitesi Veteriner Fakültesi Dergisi. 18 (1): 55-58.

5. Brainard BM. 2015. Treatment coagulation and platelet disorders. In: Veterinary Anesthesia, Analgesia: The fifth edition of lumbs and Jones.Capter 20.Edit. Grimm, KA., Lamont, LA., Tranquilli, WJ., Green SA., Robertson, SA. John Wiley\&Sons. inc. USA. pp: 380-385.
6. Chohan AS, Greene SA, Grubb TL, Keegan RD, Wills TB, Martınez SA. 2011. Effects of $6 \%$ hetastarch (600/0.75) or lactated Ringer solution on hemostatic variables and clinical bleeding in healthy dogs anesthetized for orthopedic surgery. Vet.Anest.Anagesia. 38 (2): 94-105.

7. Çetinaslan M, Apaydın N. 2008. Köpeklerde Medetomidin-Ketamin-Atipamezol

Anestezisinin Hematolojik ve Biyokimyasal Parametrelere Olan Etkileri. Sağlık Bilimleri Dergisi. 17 (2): 110-116.

8. Gülanber EG, Kaya Ü, Aktaş M, Or E, Öztürk E, Arıkan N. 1997. Köpeklerde Asepromazin ve Ketamin Kombinasyonu ile Genel Anestezinin Kan Tablosu ve Bazı Fizyolojik Fonksiyonlara Etkisi. Veteriner Cerrahi Dergisi. 1 (1): 20-25.

9. Gülanber EG, Kaya Ü, Aktaş $M$, Düzgün $O$, Baştan A, Mutlu İ, Öztürk A, Arıkan N. 2000. Köpeklerde Medetomidin-Ketamin Anestezisinin Bazı Fizyolojik Fonksiyonlara ve Kan Parametrelerine Etkisi. Veteriner Cerrahi Dergisi. 6 (1-2): 5-9.

10. Gülanber EG, Baştan A, Taşal İ, Aktaş M, Arıkan N. 2001. Köpeklerde Midazolam ve 
Ketaminle Genel Anestesi. İstanbul Üniversitesi Veteriner Fakültesi Dergisi,.27 (2): 401-409.

11. Günay C, Sağlıyan A. 2010. Köpeklerde Ksilazin-Ketamin-Halotan ve MidazolamKetamin-İzofloran Anesteziklerinin İntraoküler Basınç Üzerine Etkilerinin Karşılaştırılması. Journal of New World Sciences Academy. 5 (1): $1-8$

12. Haskin SC. 1996. Monitoring The Anaesthetized Patients, Chapter 15: Lumb and Jones Veterinary Anesthesia. Third Ed. Ed: THURMON ve ark. Williams and Wilkins Co. U.S.A. Page: 409-424.

13. Hayat A. 2001. Köpeklerde Halotan ve Sevofluranın Bazı Klinik, Hematolojik, Biyokimyasal Değerler ile Kardiyovasküler Sistem Üzerine Etkilerinin Karşılaştırılması. Fırat Üniversitesi Sağlık Bilimleri Enstitüsü Doktora Tezi.

14. Karagül H, Altıntaş A, Fidancı UR, Sel T. 2001. Klinik Biyokimya, Kas. ANKARA: Medisan Yayınları, sy: 286-287.

15. Kaya Ü, Apaydın N, Kaya A, Koç B. 2002. Tavşanlarda Xylazine- Tiletamine- Zolazepam ve Xylazine-Ketamine Anesteziklerinin Kardiyovasküler ve Respiratorik Etkilerinin Karşılaştırılması. Veteriner Cerrahi Dergisi. 8 (34): 63-68.

16. Kayhan GE, Toprak Hİ, Aslan A, Çolak YZ, Gülhaş N, Durmuş M, Ersoy MÖ. 2013. Sezaryende Ketamin: Propofol Kombinasyonu (Ketofol) ile Anestezi İndüksiyonu. Türk Anesteziyoloji ve Reanimasyon Dergisi. 41: 131136.

17. Kennerman E, Kaya G. 2005. Egzersize Bağl Akciğer Kanaması (EIPH) Olan Atlarda Klinik, Tracheabronkoskopik, Hematolojik Bulgular ve Koagülasyon Profilinin Değerlendirilmesi. Veteriner Cerrahi Dergisi. 11 (1-2-3-4): 36-40.

18. Koç B, Sarıtaş ZK. 2004.VETERINNER ANESTEZIYOLOJI ve REANIMASYON, Medipress Matbaacılık Yayıncılık, Malatya.

19. Kurtdede A, Özlem MB, Börkü MK, Kalınbacak A. 1994. Sağlıklı Köpeklerde Xylazine ve Xylazine+Ketamin'in Kan Gazları ve Bazı Hematolojik Parametreler Üzerindeki Etkileri. Ankara Üniversitesi Veteriner Fakültesi Dergisi. 41 (3-4): 327-335.
20. Mazze RI, Callan CM, Galvez ST, DelgadoHerrera I, Mayer DB. 2000. The Effects of Sevoflurane on Cerum Creatine and Blood Urea Nitrogen Concentrations: A Retrospective, Twenty-Two-Center, Comparative Evaluation of Renal Funtion in Adult Surgical Patients. Anesth. Analg. 90: 683-688.

21. Munro J, Booth A, Nichol J. 1997. Rutine preoperative testing: a systemic review of the evidence. Health Technol Assess, 1: i-iv. 1-62.

22. Oskay B, Atalan G. 2010. Köpeklerde Medetomidin-Propofol-İsofluran Anestezisinin Hematolojik ve Biyokimyasal Parametrelere Olan Etkileri. Sağlık Bilimleri Dergisi. 19 (3): 167-174.

23. Özaydın İ, Atalan G, Uzun M, Kılıç E, Çenesiz M. 2001. Köpeklerde Medetomidin, Propofol ve Ketamin Kombinasyonunun Anestezik Özellikleri ile Klinik, Kardiyovasküler ve Respiratorik Etkilerinin Değerlendirilmesi. Kafkas Üniversitesi Veteriner Fakültesi Dergisi. 7 (1): 71-76.

24. Perk C. 2000. Monitörizasyon Yöntemleri, İstanbul Veteriner Hekimler Odası Dergisi, 2 (2): 32-36.

25. Rodgers GM, Bithell TC. 1999. The diagnostic approach to the bleeding disorders. In: wintrobe's Clinical Hematology.Eds: Lee GR, Foerster J, Lukens J, Paraskevas F, Greer JP, Rodgers GM. Lippincott Williams\&Wilkins, pp:1557-1578.

26. Sar1 M, Onmaz AC. 2011. Giardiosis'li Köpeklerde Hematolojik ve Biyokimyasal Göstergelerin Değerlendirilmesi. Sağlık Bilimleri Dergisi (Journal of Health Sciences). 20 (2): 129136.

27. Sarıtaş ZK. 1996. Küçük Hayvanlarda Preoperatif, Intraoperatif ve Postoperatif Dönemlerde S1v1-Elektrolit ve Asit-Baz Dengesi. Ankara Üniversitesi Sağlık Bilimleri Enstitüsü Seminer, ANKARA.

28. Sarıtaş ZK, Apaydın N, Zorlutuna A, Ulus F, Koç B. 2006. Köpeklerde Propofol Anestezisinin Kardiyovasküler Sisteme Etkileri ve Antioksidan Özelliği. Veteriner Cerrahi Dergisi. 12 (1-2-3-4): 24-28.

29. Skarada RT, Bednarski RM, Murr WW, Hubbell JAE. 1995. Handbook of Veterinary Anesthesia, Pharmacology of Inhalation Anesthetic Drugs. Philadelphia, London, Madrid. Chapter 10. pp:156-160. 
30. Seligsohn U, Coller BS. 2001. Clasification, clinical manifestations and evaluation of disorders of hemostasis. In: Williams Hematology.Eds: Beutler E, Lichtman MA, Coller BS, Kipps TJ, Seligsohn U, McGraw H. pp:1471-1480.

31. Şencan M. 2004. Cerrahi İşlem Öncesi Koagülasyon Testleri Bozuk Olan Hastada Ne Yapmalıyım?, Ulusal Hematoloji Kongresi, IV. Hematoloji İlk Basamak Kursu, sy.13-26.

32. Şenel OO, Koç B. 2008. Köpeklerde Kas Gevşeticilerden Mivacurium Chloride ve Cisatracurium Besylate'ın Karşılaştırılması. Veteriner Cerrahi Dergisi. 14 (1): 14-23.

33. Turgut K, Birdane MF, Börkü K, Güler L. 2000. VETERINER KLINIK LABORATUVAR
TEŞHIS. Veterinary Clinic Laboratory Diagnosis. İkinci baskı. Bölüm 4. sy. 126-162.

34. Van Lue AP, Jensen AL, Storm H, Kristensen AT. 2007. Comparative analysis of haematological, haemostatic, and inflammatory parameters in canine venous and arterial blood samples. Vet..J. 173:664-668.

35. Yılmaz B. 2000. FİZYOLJİ. ( İkinci bask1 ). Feryal Matbaacılık. Ankara. sy. 118-132. 